\title{
One-step synthesis and characterization of hydrophilic polymer microspheresimmobilized with polyphenylsulfone ultrafiltration membranes for protein rejection application
}

Panchami Heggabailu Rajashekhara

National Institute of Technology Karnataka

Arun M. Isloor ( $\square$ isloor@yahoo.com )

National Institute of Technology Karnataka

Ahmad Fauzi Ismail

Universiti Teknologi Malaysia

Research Article

Keywords: Polyphenylsulfone, polymeric microspheres, distillation-precipitation polymerization, Ultrafiltration, protein rejection

Posted Date: March 7th, 2022

DOI: https://doi.org/10.21203/rs.3.rs-1331802/v1

License: @ (i) This work is licensed under a Creative Commons Attribution 4.0 International License. Read Full License 


\section{Abstract}

An effective single-step polymerization was followed for the synthesis of hydrophilicP(MBAm-co-MAA) microspheres. The distillation-precipitation polymerization (DPP) technique utilized N,Nखmethylenebis(acrylamide) (MBAm) as a crosslinker, methacrylic acid (MAA) as a monomer, solvent acetonitrile (ACN) and an initiator 2,2-azobisisobutyronitrile (AIBN) for synthesizing the P(MBAm-co-MAA) polymer particle.Simultaneously, in the reaction system, the polymer particles were formed as a precipitateand acetonitrile from the reaction was distilled out. The reaction takes placewithoutaddition of any surfactant or stabilizers. The morphology of the resultant microspheres, which were characterized by field emission scanning electron microscopy (FESEM), transmission electron microscopy (TEM), attenuated total reflectance fourier-transform infrared spectroscopy (ATR-FTIR), X-ray diffraction (XRD), thermogravimetric analysis (TGA)and BrunauerEmmett-Teller (BET) analysis.These microspheres were used as an additive for improving the performance of the fabricated membrane. The modified membranes showed increased hydrophilicity, porosity and water uptake.Membranes also exhibitedimproved permeability $\left(63.7 \mathrm{Lh}^{-1} \mathrm{~m}^{-2} \mathrm{bar}^{-1}\right)$, flux recovery ratio (80.7\%)andthe highest protein rejection values of $94.8 \%$ (bovine serum albumin), $68.4 \%$ (pepsin), $86.9 \%$ (egg albumin) were observed. Therefore, the as-prepared membrane can potentially beusedfor protein removal from industrial wastewater.

\section{Highlights}

- The single-step distillation precipitation polymerization (DPP) technique was used to synthesizethe hydrophilicP(MBAm-co-MAA) microspheres.

- ThePPSU/P(MBAm-co-MAA) flat sheetmembranes were prepared by immersion precipitation method.

- The polymeric particle immobilized composite ultrafiltration membrane showed excellent hydrophilicity and antifouling nature.

- Prepared composite membrane exhibited improvedpermeation and the protein rejection tendency, as compared to the neat membrane.

\section{Introduction}

Proteins are bio-macromolecules having complex primary, secondary, tertiary and quaternary structures (Jeevanandam et al. 2019). Other than dilute or complex mixture, these molecules are inherently unstable and undergoes denaturation by heating, solvents and shearing (Cui 2005). The complexity of protein structure and properties, many sequence varieties and folding makes it difficult for protein separation (Kumar et al. 2015). Several conventional methods are used to separate proteins, such as affinity separation, liquid-liquid phase separation, electrophoretic and magnetic separation, etc. There are some limitations to the processes mentioned above, such as less efficiency, impurities, following complex steps for separation, thus making it difficult to follow these methods (Jeevanandam et al. 2019).

Membrane technology gave a breakthrough for separation performances. In recent years, with the increase of severe water contamination due to rapid urbanization and industrialization, the separation of protein from food and bio-related industrial wastes provokes serious environmental concerns and the need to reuse efficient materials. The presence of proteins may spike the chemical oxygen demand (COD) and biological oxygen 
demand (BOD) in the effluents of the surface water (Krishnamoorthy et al. 2011). Among various types of membranes, Ultrafiltration (UF) is extensively used in protein separation due to its separation ability based on size, charge, protein solubility, adsorption characteristics, a biological affinity for other molecules and also have the advantages of low cost, simple operationand environmental adaptability. It is a promising tool for the separation of protein in various fields like dairy(Muthukumaran et al. 2004), biotechnology(van Reis \&Zydney 2001), medical(Bauser et al. 1986), food(Daufin et al. 2001) and beverage industries (Muqeet et al. 2020). For example, dairy industries producea total organic load of about $80 \%$ while cleaning the equipment, which consists of various contaminants likemilk liquor diluted in water, fat, carbohydrates, proteins and salts that go into the water stream (Brião \&Tavares 2012). The significant amount of whey produced in dairy industries consists of valuable nutrientsand it is discharged into the rivers from the industries, leading to a serious environmental issue. Hence, removal ofproteins from the wastewater is of major environmental and economic alternative(Vedadghavami et al. 2018). In biotechnology, protein-virus separation, protein production/concentration and improving the protein transmission in the purification of vaccine which can be used in the biopharmaceuticals, sterile filtration of protein solutions, amino acids, etc (van Reis \&Zydney 2001). In all these areas, protein fouling is of major concern in all the industries, which causes poor efficiency in the permeation and separation. Considering the structure and properties of proteins and the fouling behavior of the ultrafiltration membrane, removal of protein or the separating individual proteins during production or from industrial wastewater is a hot topic forthe present situation. Jayalakshmi et al. (Jayalakshmi et al. 2012) prepared cellulose acetate/epoxidated polyethersulfoneultrafiltration membrane, which showed enhanced separation efficiency of bovine serum albumin, pepsin, trypsin and egg albumin proteins as well as good fouling propensity. Krishnamoorthy et al. (Krishnamoorthy et al. 2011) fabricated cellulose acetate/poly(vinyl chloride) blend UF membranes, where PEG was used as an additive. The lower rejection of bovine serum albumin, egg albumin, trypsin and pepsin showed in the presence of an additive and flux is higher for the blend membranes.

The protein transport can be controlled by varying the charge on its surface and the extent of the charge present on the membrane matrix/interfaces. Thus, intensive research is in progress on protein transmission and rejection using polyphenylsulfone (PPSU) membranes. However, not much focus was given to PPSU for UF applicationsand present investigations are aimed to confirm the reliability of the process of PPSU ultrafiltration in protein separation (Kumar et al. 2021, Lawrence Arockiasamy et al. 2013, Rajesh et al. 2011). UF membranes are often prone to fouling by non-specific protein adsorption on the surface of the membrane through electrostatic interactions or hydrophobic nature. Considering numerous factors during the separation process, membrane fouling plays a vital roleand multiple practical applications have been employed to resist fouling. Currently, researchers are involved in the preparation of high flux performance with fouling resistantpolymeric ultrafiltration membrane(Moideen K et al. 2016). During protein separation, protein adsorption is a major concern and one of the promising alternate methods is to use non-fouling materials such as hydrophilic core microsphere polymeric particles.

Polymeric microspheres are attracting the attention of researchersfor wide range of applications, including chromatographic separation (Wang et al. 2003), biotechnology (Ma \&Su 2013), medicine (Saralidze et al. 2010) and chemical industries(Hua et al. 2013). Depending upon the application, controlled polymer microstructure, i.e., its micrometer and submicrometer size range, is of major interest(Liu et al. 2007). Such polymeric particles can be synthesized by various techniques including emulsion polymerization(Kureha et al. 2017), suspension polymerization(Lv \&Li 2020) and dispersion polymerization(Liu et al. 2020) to form different polymeric particles such as core-shell, microdomain, hollow sphere, core corona and interpenetrating polymer network(Huang et al. 
2010). Emulsion polymerization and dispersion polymerization are time-consuming processes and are used for the synthesis of polymeric microspheres. To avoid particle agglomeration, these above processes utilize suitable surfactants in an aqueous solution and to stabilize the polymeric phase, stabilizers are used in theorganic solutions. Precipitation polymerization is a method to get polymeric microspheres with uniform shape and size, leading to narrow dispersion and it is free of surfactants and stabilizers. The main limitation of this method is difficult to get a hydrophilic polymer microsphere with monodisperse proper spherical size and shape. Also it is not appropriate for large-scale preparations (Bai et al. 2006a, Bai et al. 2006b). During microsphere production, it is more often facing a problem of removing the surfactant or stabilizers and these give rise to the impure products and enhance fabrication cost. Considering all these limitations, Yang and Huang established the distillation-precipitationmethod as a novel approach to synthesize the uniform-sized and uniform-shaped polymeric microspheres, free of any surfactant or stabilizers (Liu et al. 2017, Wang et al. 2017).

Distillation-precipitation polymerization (DPP) is a novel techniqueimplemented in the large-scale production of cross-linked polymer nano/microparticles. Since efficient mixing of reactants using refluxing solvents, acetonitrile $(\mathrm{ACN})$ is preferred, than protic solvents like ethanol or methanol, which forms aggregates through hydrogen bonding. The reaction temperature plays asignificant role and it can be easily controlled. This leads to the efficient production of the core/shell microspheres with polymer shell (Ibrahim et al. 2017a, Wang et al. 2017). Nowadays, monodisperse functional polymeric particles have been found broad application as protein carriers in the field of immunodiagnostic arrays, in solid-phase peptide synthesis as insoluble support and stationary phase for chromatography and catalysis. Such uniform polymer shells provide an efficient functional group that can be utilized in the application of protein separation (Li et al. 2005).

Wang et al. (Wang et al. 2017) fabricated $\mathrm{Fe}_{3} \mathrm{O}_{4} @ \mathrm{SiO}_{2} @ p V B C @ I L$ magnetic composite polymer particles wheremagnetic $\mathrm{Fe}_{3} \mathrm{O}_{4}$ coremicrosphere and an imidazolium modified poly-4-vinyl benzyl chloride (PVBC) shell prepared via the DPP method. Itshowed higher efficacy and good selectivity in the hemoglobin isolation from a mixture of protein and human blood samples. It is also used before proteomic analysis to isolate high abundant protein from the given samples. Ma et al. (Ma et al. 2011) developed a magnetic microsphere $\left(\mathrm{Fe}_{3} \mathrm{O}_{4}\right) /$ poly(methacrylic acid) (PMAA) hybrid hydrophilic polymer particlethat was synthesized through encapsulating $y$-methacryloxypropyltrimethoxysilane (MPS)-modified magnetite colloid nanocrystal clusters (MCNCs) with cross-linked PMAA shell by distillation precipitation polymerization method. Prepared core-shell possesses excellent morphology and good pH sensitivity. The number of carboxylic groups present in the coreshell with bioactive molecules can be easily functionalized, which results in a higher potential in bioseparation and biomedical application. Han et al.(Han et al. 2019) synthesized polymeric microspheres $\mathrm{SiO}_{2} \mathrm{Coated}^{\mathrm{Fe}} \mathrm{CO}_{3}$ magnetic core and $\mathrm{Ni}^{2+}$ immobilized cross-linked poly( $\mathrm{N}$-isopropyl acrylamide-co-propylimidazole)shell via DPP method. The microsphere has a good adsorption capacity. The $\mathrm{Ni}^{2+}$ cations give docking sites for histidine and show a higher bromelain proteolytic enzyme separation with a binding capacity of $198 \mathrm{mgg}^{-1}$. The utilization of polymeric microsphere has anexcellent opportunity for protein separation.

Based on the above observations, in our present work,the distillation-precipitation polymerization technique was followed to synthesize $\mathrm{P}(\mathrm{MBAm}-$ co-MAA) polymer particles using a monomer N,N囚- methylenebis(acrylamide) (MBAm) as a crosslinker, methacrylic acid (MAA) as a monomer, solvent acetonitrile (ACN) and an initiator 2,2azobisisobutyronitrile (AIBN). The prepared microspheres were characterized byattenuated total reflectance fourier-transform infrared spectroscopy (ATR- FTIR),transmission electron microscopy (TEM), field emission 
scanning electron microscopy (FESEM), energy-dispersive X-ray spectroscopy (EDX), thermogravimetric analysis (TGA), X-ray diffraction (XRD), particle size andzeta potential studies. The neat PPSU and PPSU/P(MBAm-coMAA) composite membranes were fabricated with different dosages of polymer particlesvia immersion precipitation process. The prepared membranes were investigatedusing FESEM, EDX,water uptake capacity, contact angle, porosity,zeta potential, pure water flux studies and antifouling studies. Also, the as-prepared membranes were evaluated for the individual protein permeation and separation efficacy.

\section{Experimental Section}

\section{Materials}

Polyphenylsulfone (PPSU of Molecular weight (MW) 50,000 $\mathrm{gmol}^{-1}$ ) Radel R-5000 was procured by Solvay Advanced polymer, Belgium. N-methylpyrrolidone (NMP, 99.8\%) and acetonitrile (ACN, 99.9\%) solvents were purchased from Loba Chemie Pvt. Ltd., India. Polyvinylpyrrolidone (PVP K-30), N,N囚-methylenebis(acrylamide) (MBAm, 99\%), methacrylic acid (MAA, 99\%), azobisisobutyronitrile (AIBN, 98\%) from Sigma Aldrich, India, Bovine Serum Albumin (BSA, 98\%, MW 66 kDa) from HiMedia Laboratories Pvt. Ltd., India. Egg albumin (EA, MW 44 $\mathrm{kDa}$ ) and pepsin (PP, MW $34 \mathrm{kDa}$ ) were obtained from Central Drug House (P) Ltd., India.

\section{Synthesis of $\mathrm{P}(\mathrm{MBAm}-\mathrm{co}-\mathrm{MAA})$ microspheres}

The synthesis of hydrophilic $\mathrm{P}(\mathrm{MBAm}-\mathrm{co}-\mathrm{MAA})$ microspheres by distillation-precipitation polymerization were followed according to the literature (Liu et al. 2016). Briefly, MBAm (1.0 g, $6.4 \mathrm{mmol}), \mathrm{MAA}(0.053 \mathrm{~mL}, 0.055 \mathrm{~g}$, $0.63 \mathrm{mmol})$, and AIBN $(0.0225 \mathrm{~g}, 0.13 \mathrm{mmol})$ were dissolved in ACN $(100 \mathrm{~mL})$ in a dried $250 \mathrm{~mL}$ round bottom flask. Nitrogen gas was purged for $10 \mathrm{~min}$ and the RBF was connected with a Dean-Stark receiver and the condenser. The reaction temperature was slowly raised to $75^{\circ} \mathrm{C}(10 \mathrm{~min})$ with continuous stirring using Remi magnetic stirrer with hotplate, $2 \mathrm{MLH}$ at $500 \mathrm{rpm}$. The reaction was kept under reflux and the temperature was gradually increased $\sim 110^{\circ} \mathrm{C}$. Then, half of the solvent was distilled off from the reaction mixture within $2 \mathrm{~h}$. After the polymerization, the flask was removed and the obtained product was purified by centrifugation to remove the residual oligomers and unreacted monomers by ACN. The synthetic route of the reaction is as shown below in Fig. 1.

\section{Figure-1}

\section{Fabrication of the ultrafiltration membranes}

For the preparation of PPSU/P(MBAm-co-MAA) flat sheet membranes, the immersion precipitation method was employed. Table 1 follows the composition of the dope solution. Initially, the calculated amount of $0.1 \mathrm{~g}, 0.2 \mathrm{~g}$, $0.3 \mathrm{~g}$ of $\mathrm{P}(\mathrm{MBAm}-\mathrm{co}-\mathrm{MAA})$ was dispersed in NMP solvent by ultrasonication ( $40 \mathrm{kHz}, 60 \mathrm{~W}$ spectra lab) for 30 min, further addition of the microsphere leads to agglomeration and make the dope solution more viscous. To the above-dispersed solution, the PPSU and PVP were added and continuously stirred for $24 \mathrm{~h}$, then degassing of the dope solution was allowed for about $20 \mathrm{~min}$ to remove the air bubbles. Thus obtained air bubble-free dope solution was cast over a glass plate using $100 \mu \mathrm{m}$ steel rod using membrane casting equipment (automatic K202 control coater) and gently immersed in the deionized water (coagulation bath) for $24 \mathrm{~h}$ at room temperature for complete phase inversion with periodic changing of deionized water to remove residual solvents(Hebbar et al. 2014). 


\section{Table-1}

\section{Characterization of the synthesized P(MBAm-co-MAA) microspheres}

The functional group present in MBAm, MAA and P(MBAm-co-MAA) polymer particle was identified by attenuated total reflectance fourier-transform infrared spectroscopy (ATR- FTIR), using a Bruker IR spectrophotometer in the range of $4000-500 \mathrm{~cm}^{-1}$. Transmission electron microscopy (TEM) and field emission scanning electron microscopy (FESEM) are the microscopic techniques used to analyze the structural morphology of the synthesized P(MBAm-co-MAA) microspheres using JEOL JEM-2200 FS and Carl Zeiss AG, Model: Gemini SEM 300 instruments respectively. Also, before commencing the FESEM analysis, the samples were dried and were smeared with gold using a sputtering device to avoid charging. The elemental composition was analyzed using energy-dispersive X-ray spectroscopy (EDX) (EDAX-AMETEK). The thermogravimetric analysis (TGA) (Perkin Elmer 4000) was performed under nitrogen atmosphere by heating samples at a rate of $10^{\circ} \mathrm{C} \mathrm{min}^{-1}$ from $25^{\circ}-800^{\circ} \mathrm{C}$. The surface area, mean pore radius and pore volume were assessed using the Bruner-Emmet-Teller (BET). The polymer particle's zeta potential and hydrodynamic diameter were analyzed using a nanoparticles analyzer (Anton Paar). The synthesized P(MBAm-co-MAA) particles was investigated using XRD analysis (Malvern PANalytical: Empyrean X-ray diffractometer in the range of 5 to $80^{\circ}$ using $\mathrm{Cu} \mathrm{Ka}$ as an X-ray source).

\section{Membrane Characterization}

The cross-sectional morphology of the membrane was analyzed by field emission scanning electron microscopy (FESEM) using an instrument Carl Zeiss AG, Model: Gemini SEM 300 and the elemental composition or chemical characterization of the membrane was done using energy-dispersive X-ray spectroscopy (EDX) (EDAX: AMETEK). The surface topography of the prepared pristine and PPSU/P(MBAm-co-MAA) membranes was analyzed using the Bruker nanoscope multimode 8 Atomic force microscopy (AFM) instrument. To conduct the AFM analysis by tapping mode, dry membrane samples were placed on a surface with a scan area of $2 \mu \mathrm{m}^{2}$. To analyze the surface roughness parameters like average roughness $\left(R_{a}\right)$, root mean square roughness $\left(R_{q}\right)$ and roughness maximum $\left(R_{\max }\right)$ nanoscope analysis software was used(Kumar et al. 2019, Moideen et al. 2018). The changes in the surface hydrophilic nature of the prepared membrane were observed using the Kruss drop shape analyzer DS-100 instrument by the sessile drop method(Hebbar et al. 2017). To get the precise value, an average of three different locations of each sample was taken for analysis(Shenvi et al. 2016). To identify the elements present within the membrane was characterized using X-ray photoelectron spectroscopy using X-ray source (Al Ka radiation) with a take-off angle of $20^{\circ}$. The electrokinetic analyzer (Surpass Anton Paar) was used to measure the Zeta potential of the membrane surface using the background electrolyte of $0.001 \mathrm{M} \mathrm{KCl}, 0.1 \mathrm{M}$ of HCl and $0.1 \mathrm{M}$ of $\mathrm{NaOH}$ are used for changing the $\mathrm{pH}$.

The water content of the as-prepared pristine and composite membranes $\left(2 \mathrm{~cm}^{2}\right)$ was determined by dipping the membranes in distilled water for $24 \mathrm{~h}$. The wet membranes weight was noted after removing excess water using blotting paper. Then the wet membranes were dried at $60{ }^{\circ} \mathrm{C}$ till constant weight and dry weights were determined (Nayak et al. 2017, Nayak et al. 2018). The equation for percentage water content was calculated as follows,

$$
\% \text { Wateruptake }=\left(\frac{W W-W d}{W W}\right) X 100
$$


Where ' $W_{w}$ ' and ' $W_{d}$ ' are the wet weight and the dry weight of the membrane respectively. The porosity $(\epsilon)$ in percentage is given in an equation as follows,

$$
\in(\%)=\frac{(W w-W d)}{A l d w} X 100
$$

\section{2}

Where ' $\mathrm{l}$ ' is the thickness of the membrane $(\mathrm{m})$, ' $A$ ' is the membrane area $\left(\mathrm{m}^{2}\right)$ and ' $\mathrm{d}_{\mathrm{w}}$ ' is the pure water density $\left(0.998 \mathrm{~g} \mathrm{~cm}^{-3}\right)$.

The MWCO gives the idea of pore size distribution and retention capabilities of the membrane provide a clear picture of the filtration and separation performances. It is interpretated as the lowest molecular weight of the solute having rejection above $90 \%$. The MWCO of the membrane can be determined by the following procedure (Ibrahim et al. 2018). In brief, polyethylene glycol (PEG) of different molecular weights of 2000, 4000, 6000, 10000 and 20000 Da were chosen. The filtration studies were performed using 100 ppm of individual PEG solutions at 2 bar pressure. The concentrations of PEG feed and permeate was analyzed using TOC-L SHIMADZU TOC analyzer. The MWCO rejection percentage was determined by the following equation,

$$
\text { Rejection } \%=\left(1-\frac{C p}{C f}\right) \times 100
$$

3

Where ' $C_{p}$ ' and ' $C_{f}$ ' are the concentration of permeate and feed polyethylene glycol samples respectively.

The filtration experiments were performed by utilizing a lab-scale cross-flow filtration setup. The membrane of the effective surface area of $28.27 \mathrm{~cm}^{2}$ was chosen. Initially, the pure water permeation of the membranes was subjected to 30 min compaction at 3 bar pressure followed by measuring the flux for 100 min at 2 bar pressure. It was calculated by the following equation,

$$
Q w 1=\frac{q}{A \Delta t}
$$

\section{4}

Where ' $\mathrm{Q}_{\mathrm{w} 1}$ ' $\left(\mathrm{Lm}^{-2} \mathrm{~h}^{-1}\right)$ is the pure water flux (PWF), ' $\mathrm{q}$ ' is the permeate water collected $(\mathrm{L})$ for ' $\Delta \mathrm{t}^{\prime}(\mathrm{h})$ is time taken using the surface area of the membrane ' $A$ ' $\left(m^{2}\right)$.

The prepared membrane showed antifouling character and was determined according to the literature(Zhang et al. 2013). In brief, the membrane was subjected to 30 min compaction at 3 bar pressure, then pure water permeation for 100 min at 2 bar pressure was determined ' $\mathrm{Q}_{\mathrm{w} 1}{ }^{\prime}\left(\mathrm{Lm}^{-2} \mathrm{~h}^{-1}\right)$. The solution of $800 \mathrm{ppm}$ of BSA was prepared and protein flux for about $100 \mathrm{~min}$ at 2 bar pressure was noted, where BSA was chosen as a model protein foulant, which gives ' $\mathrm{Q}_{\mathrm{p}}$ ' $\left(\mathrm{Lm}^{-2} \mathrm{~h}^{-1}\right)$. After BSA filtration, the membrane was taken out from the set-up and washed with continuous distilled water for $10 \mathrm{~min}$ and again pure water permeation study was performed and noted as, ' $\mathrm{Q}_{\mathrm{w} 2}$ ' $\left(\mathrm{Lm}^{-2} \mathrm{~h}^{-1}\right)$ for $100 \mathrm{~min}$ at 2 bar pressure. The resistance for membrane fouling was calculated by flux recovery ratio (FRR) as follows(Ibrahim et al. 2020b), 


$$
F R R(\%)=\left(\frac{Q w 2}{Q w 1}\right) \times 100
$$

5

The fouling nature of the membranes were further studied in terms of total fouling ratio $\left(R_{t}\right)$, reversible fouling ratio $\left(R_{r}\right)$ and irreversible fouling ratio $\left(R_{\text {ir }}\right)$ by the following equations,

$$
R r(\%)=\frac{Q w 2-Q p}{Q w 1} \times 100
$$

6

$$
\operatorname{Rir}(\%)=\frac{Q w 1-Q w 2}{Q w 1} \times 100
$$

7

$$
R t(\%)=\frac{Q w 1-Q p}{Q w 1} \times 100
$$

8

The 500 ppm solution of individual proteins such as bovine serum albumin (BSA), egg albumin (EA), and pepsin (PP) were dissolved in phosphate buffer $(0.05 \mathrm{M}, \mathrm{pH} 7.2)$ and were prepared(Glazer et al. 1973). Each protein solution was taken in a feed tank and passed through all the pristine and composite membranes separately at 2 bar pressure. The collected feed and permeate were analyzed by a Analytik Jena SPECORD S 600 UV-Visible Spectrometer equipment for BSA $(280 \mathrm{~nm})$ and EA $(280 \mathrm{~nm})$, PP $(275 \mathrm{~nm})$. The protein flux of individual proteins was noted for $100 \mathrm{~min}$ at 2 bar pressure. The equation for rejection percentage is as follows,

$$
\% R=\left(1-\frac{C p}{C f}\right) \times 10
$$

9

Where ' $C_{f}$ ' and ' $C_{p}$ ' are the feed concentration and the permeate concentration of individual protein solution respectively.

\section{Results And Discussions}

\section{Characterization of P(MBAm-co-MAA) microspheres}

The ATR-FTIR spectra of MBAm, MAA and P(MBAm-co-MAA) are represented in Fig. 2. The peaks for MBAm at $3308,1657,1626$ and $1543 \mathrm{~cm}^{-1}$ were attributed to the $\mathrm{N}-\mathrm{H}$ stretching, amide $\mathrm{C}=\mathrm{O}$, alkene $\mathrm{C}=\mathrm{C}$ stretching vibrations and bending vibrations of $\mathrm{NH}-\mathrm{CO}$ respectively (Ibrahim et al. 2020a). The MAA exhibits peaks at 1631 $\mathrm{cm}^{-1}$ corresponds to vinyl functional group, $1201 \mathrm{~cm}^{-1}$ ascribed to C-O stretching vibrations and $1375 \mathrm{~cm}^{-}$ ${ }^{1}$ represents stretching vibrations of 0 -Hcarboxylic group. The synthesized $\mathrm{P}(\mathrm{MBAm}-\mathrm{co}-\mathrm{MAA})$ polymer particle showed the peaks at $1653 \mathrm{~cm}^{-1}$ corresponds to $\mathrm{C}=0$ stretching, $1530 \mathrm{~cm}^{-1}$ forNH-CO stretching, $3329 \mathrm{~cm}^{-1}$ forN$\mathrm{H}$ stretching and also, 1219 and $1384 \mathrm{~cm}^{-1}$ represents stretching vibrations of C-O group and stretching 
vibrations of O-Hcarboxylic group respectively(Liu et al. 2016). The peaks of $1626 \mathrm{~cm}^{-1}$ of $\mathrm{C}=\mathrm{C}$ of MBAm and $1631 \mathrm{~cm}^{-1}$ of $\mathrm{C}=\mathrm{C}$ of MAA were not observed in $\mathrm{P}(\mathrm{MBAm}-\mathrm{co}-\mathrm{MAA})$, which confirmed the complete polymerization reaction. To characterize the morphology of the synthesized P(MBAm-co-MAA) particles, FESEM and TEM were employed, as shown in Fig. 3. The particles are approximately spherical with a rough surface of diameter $300 \mathrm{~nm}$. The plausible reason is that during polymerization, the ability of the remaining $C=C$ on the surface of $\mathrm{P}(\mathrm{MBAm}-\mathrm{co}-\mathrm{MAA})$ was not efficient enough from the solution to form bonds with newly formed oligomers, which results in the morphology of cauliflower-like particles with the rough surface (Liu et al. 2007, Liu et al. 2018b).The presence of elements such as carbon, oxygen and nitrogen were analyzed and confirmed by EDX and elemental mapping as shown in Fig. 4. The atomic weight percentage of the elements is $79.80 \%$, $13.05 \%$ and $7.15 \%$ for carbon, nitrogen and oxygen, respectively. The selected area electron diffraction (SAED) image consists of diffused rings proved the amorphous nature of the prepared polymer particle shown in Fig. $3 \mathrm{~d}$.

\section{Figure-2}

\section{Figure-3}

\section{Figure-4}

The XRD analysis spectra of the synthesized P(MBAm-co-MAA) particle is as shown in Fig. 5a. The XRD pattern shows that the synthesized particle is amorphous in nature. The same XRD pattern was reported elsewhere (Jyoti et al. 2021). The amorphous nature of the materials is also proved by the SAED pattern mentioned in Fig. $3 \mathrm{~d}$. The adsorption-desorption isotherm for the microsphere was investigated by Brunauer-Emmett-Teller (BET) is as shown in Fig. 5b. From nitrogen adsorption-desorption isotherm, we can conclude that the synthesized particle represents a type IV isotherm with a H3 hysteresis loop. According to thelnternational Union of Pure and Applied Chemistry classifications, the prepared microspheres consist of both microporous and mesoporous nature, which infers a slit-shaped pore is present(Faheem et al. 2019, Li et al. 2017). The particles BET surface area, pore radius and pore volume were $50.42 \mathrm{~m}^{2} \mathrm{~g}^{-1}, 0.70 \mathrm{~nm}$ and $0.10 \mathrm{ccg}^{-1}$, respectively. The adsorption curves of the synthesized particle are not closed, the plausible reason behind it is the swelling phenomena of the polymeric particle (Yang et al. 2018). The surface charge of the polymer particle exhibited $-39.4 \mathrm{mV}$, as shown in Fig. $5 \mathrm{c}$. This is due to the - $\mathrm{COOH}$ group present in the synthesized P(MBAm-co-MAA). The hydrodynamic diameter of the particles was $406.3 \mathrm{~nm}$ which has been presented in Fig. $5 \mathrm{~d}$ slightly higher than the size measured in the TEM. When the polymeric particles dissolve in the suitable solvents, they will get swollen and in a dry state, they will get collapsed (Ma et al. 2011). The thermal stability of the synthesized P(MBAm-co-MAA) was analyzed by TG analysisand shown in Fig. 5e. The TGA curve exhibits threestages of weight loss. The first stage below $130^{\circ} \mathrm{C}$ is due to the removal of residual adsorbed moisture in the polymer. The second significant stage between $242.4^{\circ} \mathrm{C}$ $-400^{\circ} \mathrm{C}$ corresponds to the decomposition of remaining carboxylic and amine groups of MBAm and the third stage between $400^{\circ} \mathrm{C}-487.79^{\circ} \mathrm{C}$ corresponds to the main polymer chain decomposition.

\section{Figure-5}

\section{Characterization of the prepared membrane}

The cross-sectional membrane morphology is shown in Fig. 6. The neat (M-0) membrane has less vertical microvoids and few horizontal macro voids. As the dosage of the polymeric particles increases, there was an increase in vertical microvoids, which is visible in M-1 and M-2 membranes. The vertical microvoids extend up to 
the bottom of the membrane lead to the ease of water flow than the horizontal macrovoids. This can be attributed to the hydrophilic carboxylic group and amide group present in the microsphere. However, for the M-3 membrane, the finger-like voids throughout the membrane and spongy nature at the bottom of the membrane slightly resist the water flow as compared to the M-2 membrane. This is due to the decrease in the hydrophilic nature of the membrane. The incorporation of the polymer particle can be confirmed by EDX and the elemental mapping as shown in Fig. 7. Carbon, nitrogen and oxygen on the membrane matrix M-2 confirm the incorporation of polymer particles and the presence of a sulfur element is due to the PPSU polymer used to prepare the membrane.To further validate the existence of microsphere in the membrane matrix was examined by XPS analysis as shown in Fig. 8a, the characteristic binding energy peaks for S 2p, C 1s, N 1s and O 1s at $166.43 \mathrm{eV}$, $282.94 \mathrm{eV}, 398.31 \mathrm{eV}$ and $531.69 \mathrm{eV}$ respectively are noted. These values correlate with the literature(Ibrahim et al. 2017b). The charge present on the membrane influences the separation efficacy of the ultrafiltration membrane. The negative charge in all the membranes is more than the $\mathrm{M}-0$, as shown in Fig. $8 \mathrm{~b}$, attributes to the carboxylic group present on the membrane matrix. The carboxylate ions are protonated as the $\mathrm{pH}$ decreases towards the acidic side, which causes shrinkage in the double layer thickness. The isoelectric point (IEP) 2.10, 2.22,2.25, 1.93 for M-0, M-1, M-2 and M-3 respectively. The Molecular cutoff of the membrane M-2 is $18107 \mathrm{Da}$, shows it is an ultrafiltration membrane in Fig. 8c.

\section{Figure-6}

\section{Figure-7}

\section{Figure-8}

The effect of the synthesized P(MBAm-co-MAA) particle on the contact angle, water uptake capacity, and porosity of the prepared membrane is presented in Table 2. By increasing the addition of P(MBAm-co-MAA) particles, the porosity was gradually improved and it was enhanced by $37.8 \%$ for the $\mathrm{M}-1$ membrane as compared to the $\mathrm{M}-0$ membrane. The maximum porosity was observed at $72.6 \%$ for the $M-2$ membrane. The same trend was observed for the water uptake of the composite membrane. The hydrophilicity of the microsphere leads to an increase in the demixing rate between the solvent and non-solvent which is responsible for the porous structure of the membrane. However, the porosity decreased with $0.3 \mathrm{~g}$ of $\mathrm{P}(\mathrm{MBAm}-\mathrm{co}-\mathrm{MAA})$ particle, the same trend was observed in the contact angle as well as the water uptake. This can be attributed to the addition of a higher dosage of microspheres, which leads to agglomeration and make the dope solution more viscous. The contact angle of the composite membrane was reduced with the addition of $\mathrm{P}(\mathrm{MBAm}-\mathrm{CO}-\mathrm{MAA})$ particles having carboxylic groups of MAAand amide groups of MBAm. The M-2 membrane has the lowest contact angle of $69.9^{\circ}$ compared to $87.3^{\circ}$ in $\mathrm{M}-0$ membrane.

\section{Table-2}

The AFM 3D images in Fig. 9 of the membrane were analyzed in theAFM instrument(Model Bruker nanoscope multimode 8) to observe the membrane topology. Using scan area of $2 \mu \mathrm{m}^{2}$ with the tapping mode following parameters were studied such as average roughness $\left(R_{a}\right)$, root mean square roughness $\left(R_{q}\right)$ and roughness maximum $\left(R_{\max }\right)$ given in Table 3 and analyzed surface roughness by the Nanoscope analysis software. The average roughness of the membrane $\left(R_{a}\right)$, root mean square roughness $\left(R_{q}\right)$ and maximum roughness depth $\left(R_{\max }\right)$ increased in the composite membrane compared to M-0 which indicates that the presence of more 
cavities and surface roughness, promotes permeation of the composite membrane (Isloor et al. 2019). Riedl et al. (Riedl et al. 1998) explained that a loose fouling layer was formed at the rough membrane surface causing lower flow resistance compare to smooth surface with dense fouling layers. Addition of P(MBAm-co-MAA) polymer particle increases the hydrophilicity of the membrane helps to attract water molecule compared to pristine $\mathrm{M}-0$ membrane and thus lower contact angle improved the antifouling character of the membrane (Liu et al. 2018a).

\section{Figure-9}

\section{Table-3}

The composite membranes showedan increase in the pure water permeability as the microspheres concentration increases as shown in Fig. $8 \mathrm{~d}$. The M-2 membrane exhibited maximum permeability compared to the MOmembrane. The increase in permeability may be attributed to the porosity and the hydrophilicity of the membranes and it follows the same trend. The highest pure water permeability showed by M-2 was $63.7 \mathrm{Lh}^{-1} \mathrm{~m}^{-}$ ${ }^{2}$ bar $^{-1}$ which was more than pristine $35.3 \mathrm{Lh}^{-1} \mathrm{~m}^{-2}$ bar $^{-1}$ and the flux of M-2 and M-0 was $127.4 \mathrm{Lm}^{-2} \mathrm{~h}^{-1}$ and $70.6 \mathrm{~L} \mathrm{~m}^{-2} \mathrm{~h}^{-1}$ respectively. AFM results also confirmed the membrane surface favors for pure water permeation as shown in Fig. 9. The antifouling capacity of the prepared membrane is shown in Fig. 10a. The time-dependent study was performed to analyze the antifouling nature using BSA. Initially, pure water flux was determined for 100 min and observed thatthe flux of the membrane was slightly declined which was due to the mechanical deformation. Further on continuing the filtration studies with BSA, a sudden decrease in the flux was observed. The BSA protein molecules adsorbed on the surface of the membrane blocked the membrane pores and the flux declined gradually. Then the membrane were washed in running tap water and again pure water flux were measured. The flux obtained after BSA studies was slightly improved and all these fouling capacities of the prepared membrane were analyzed in terms of fouling parameters such as flux recovery ratio (FRR), total fouling $\left(R_{t}\right)$, reversible fouling $\left(R_{r}\right)$, irreversible fouling $\left(R_{i r r}\right)$ as shown in Fig. 10b. All these parameters infer that the addition of polymer particles helps in forming the hydration layer above the membrane, leading to the decrease in the adsorption of foulants. The protein-membrane interactions affect the irreversible adsorption on the membrane surface and within pores. The detailed fouling parameters were given in Table 4. The recycling capacity of the hybrid membrane wereevaluated by calculating the flux recovery ratio (FRR) which increases up to $85.2 \%$ for $\mathrm{M}-2$ than $\mathrm{M}-0$ of $50.4 \%$. The total fouling of the membrane decreased from $60.7-37.7 \%$ for $\mathrm{M}-0$ and M-2 respectively. The same trend was followed by irreversible fouling by $49.5-14.7 \%$ for M-0 and M-2 respectively. For reversible fouling, the $\mathrm{M}-0$ membrane shown $11.2 \%$ after adding the polymer particles, it increased to $22.9 \%$ for the M-2 membrane. These studies showed the improvement of the antifouling nature of the membrane.

\section{Figure-10}

\section{Figure-11}

\section{Table-4}

\section{Table-5}

The separation of protein from the water is of great importance and it is possible by exploiting repulsive electrostatic interactions. Hence, it is always helpful for protein separation by considering the combination of 
charge and size-based selectivity for improving the performances of the membrane (Kumar \&Ulbricht 2013). In the present work,egg albumin (EA),bovine serum albumin (BSA) andpepsin (PP) proteins were evaluated. The M2composite membraneexhibited the highest rejection of $94.8 \%, 68.4 \%$, and $86.9 \%$ for BSA, PP and EA, respectively. The higher molecular weight of BSA showedmaximum rejection which was more thanEA and PP, i.e., following the size-exclusion principle the lower molecular weight molecules will pass through the membrane easily. The higher addition of polymer particles up to the M-2 membrane exhibited maximum protein rejection as shown in Fig. 11a, which follows the porosity and hydrophilicity trend. The IEP of BSA (4.5-5.0) (Phan et al. 2015), PP ( 1) (Sepelyak et al. 1984), andEA (4.8) (Delfiya et al. 2016) whereproteins are positively charged at below IEP and negatively charged atabove IEP. The electrostatic repulsion occurs between proteins and the membrane surface possesses a negative charge at a neutral $\mathrm{pH}$. Hence, the composite membranes showed maximum rejection at neutral $\mathrm{pH}$. The zeta potential analysis of the membrane presented in Fig. 8brevealsthat, the negative charge of the membrane at neutral $\mathrm{pH}$ directly reflects in the protein rejection (Jafar Mazumder et al. 2020). The detailed studies of proteins such as BSA, EAand PP permeation flux are shown in Fig. 11b, 11c, 11dand given in Table 5. The maximum permeability of the M-2 membrane is due to its highest hydrophilic and porosity nature. The presence of hydrophilic carboxylic and amide groups in the microsphere on the membrane's active surface attracts more water molecules leavingbehind proteinmolecules. In addition, as the porosity increases, the lower molecular weight of the protein molecule will easily pass through the membrane than the higher molecular weight.

\section{Conclusions}

Single-step synthesis of polymer particles of $\mathrm{P}(\mathrm{MBAm}-\mathrm{co}-\mathrm{MAA})$ microspheres using the distillation precipitation polymerization (DPP) technique and incorporated into the PPSU ultrafiltration membranes. Among the neat and composite membranes, the composite membranes have higher hydrophilicity and porosity than the neat membrane, which influences on the membrane performances. The addition of polymer particles affects membrane hydrophilic nature, indicating a slight decrease in the contact angle from $87.3^{\circ}$ of $\mathrm{M}-0$ to $69.9^{\circ}$ in the M-2 membrane, attributed to the hydrophilic carboxylicand amide group present in the microsphere on the polymer matrix. The highest PWF of the membrane M-2 (127.4 $\left.\mathrm{Lm}^{-2} \mathrm{~h}^{-1}\right)$ than M-0 $\left(70.6 \mathrm{Lm}^{-2} \mathrm{~h}^{-1}\right)$ and the flux recovery ratio increased from $50.4-80.7 \%$ of M-0 and M-2 membrane, respectively. Compared to neat membranes rejections of $68.6 \%$ (BSA), 36.2\% (egg albumin) and $40.1 \%$ (pepsin), M-2 membranes showed the much-improved rejections of $94.8 \%$ (BSA), $86.9 \%$ (egg albumin) and $68.4 \%$ (pepsin). Considering all the improved properties of the prepared PPSU/P(MBAm-co-MAA) composite membrane, we can conclude that fabricated new membranes are promising for protein rejection application.

\section{Declarations}

Acknowledgments:The authors are thankful to the Director of the National Institute of Technology Karnataka, Surathkal, India for providing the research facilities. AMI is thankful to Vision Group on Science and Technology, Govt. of Karnataka for the CESEM award. AMI also thankful to Dr.Rajmohan, Department of Chemical engineering, and HEFA-CRF. The authors are thankful to the Heads of the Department of Chemical Engineering, Department of Metallurgy and material science, Department of Physics of NITK Surathkal, India for assisting in analytical studies. 
Ethical Approval : All authors hereby declare that, there are no any conflicts of interests and they have followed all the research ethics.

Consent to Participate: All authors have given their consent for participating in this manuscript as authors \& all authors roles has been justified in the next part.

Consent to Publish : All authors hereby giving their consent for publishing the article in Environmental Science and Pollution Research journal. This manuscript has not been published in any other journal, nor for the consideration by any other journal for publishing.

Authors Contributions: PHR performed synthetical and experimental parts, AFI performed few of the analytical studies \& AMI is the research supervisor for this work \& corrected the manuscript.

Funding : Necessary funding for this research was provided by National Institute of Technology Karnataka, Surathkal, India

Competing Interests : All authors declare that, there is no any competing interest in this manuscript.

Availability of data and materials : All data of the experiment has been provided along with the manuscript.

\section{References}

1. Bai F, Yang X, Huang W (2006a) Preparation of narrow or monodisperse poly(ethyleneglycol dimethacrylate) microspheres by distillation-precipitation polymerization. Eur Polymer J 42:2088-2097

2. Bai F, Yang X, Li R, Huang B, Huang W (2006b) Monodisperse hydrophilic polymer microspheres having carboxylic acid groups prepared by distillation precipitation polymerization. Polymer 47:5775-5784

3. Bauser H, Chmiel H, Stroh N, Walitza E (1986) Control of concentration polarization and fouling of membranes in medical, food and biotechnical applications. J Membr Sci 27:195-202

4. Brião VB, Tavares CRG (2012) Pore blocking mechanism for the recovery of milk solids from dairy wastewater by ultrafiltration. Braz J Chem Eng 29:393-407

5. Cui Z (2005) Protein separation using ultrafiltration - an example of multi-scale complex systems. China Particuology 3:343-348

6. Daufin G, Escudier JP, Carrère H, Bérot S, Fillaudeau L, Decloux M (2001) Recent and Emerging Applications of Membrane Processes in the Food and Dairy Industry. Food Bioprod Process 79:89-102

7. Delfiya DA, Thangavel K, Amirtham D (2016) Preparation of curcumin loaded egg albumin nanoparticles using acetone and optimization of desolvation process. Protein J 35:124-135

8. Faheem M, Aziz S, Jing X, Ma T, Du J, Sun F, Tian Y, Zhu G (2019) Dual luminescent covalent organic frameworks for nitro-explosive detection. J Mater Chem A 7:27148-27155

9. Glazer AN, Fang S, Brown DM (1973) Spectroscopic Properties of C-Phycocyanin and of Its a and $\beta$ Subunits. J Biol Chem 248:5679-5685

10. Han J, Wang L, Wang L, Li C, Mao Y, Wang Y (2019) Fabrication of a core-shell-shell magnetic polymeric microsphere with excellent performance for separation and purification of bromelain. Food Chem 283:1-10 
11. Hebbar RS, Isloor AM, Ismail A (2014) Preparation and evaluation of heavy metal rejection properties of polyetherimide/porous activated bentonite clay nanocomposite membrane. RSC Adv 4:47240-47248

12. Hebbar RS, Isloor AM, Ismail AF (2017) Chap. 12 - Contact Angle Measurements. In: Hilal N, Ismail AF, Matsuura T, Oatley-Radcliffe D (eds) Membrane Characterization. Elsevier, pp 219-255

13. Hua Z, Lin M, Guo J, Xu F, Li Z, Li M (2013) Study on plugging performance of cross-linked polymer microspheres with reservoir pores. J Petrol Sci Eng 105:70-75

14. Huang B, Bai F, Yang X-I, Huang W-q (2010) Synthesis of monodisperse hollow polymer microspheres with functional groups by distillation precipitation polymerization. Chin J Polym Sci 28:277-285

15. Ibrahim GPS, Isloor AM, Moslehyani A, Ismail AF (2017a) Bio-inspired, fouling resistant, tannic acid functionalized halloysite nanotube reinforced polysulfone loose nanofiltration hollow fiber membranes for efficient dye and salt separation. J Water Process Eng 20:138-148

16. Ibrahim GPS, Isloor AM, Inamuddin, Asiri AM, Ismail AF, Kumar R, Ahamed MI (2018) Performance intensification of the polysulfone ultrafiltration membrane by blending with copolymer encompassing novel derivative of poly(styrene-co-maleic anhydride) for heavy metal removal from wastewater. Chem Eng $J$ 353:425-435

17. Ibrahim GS, Isloor AM, Asiri AM, Ismail N, Ismail AF, Ashraf GM (2017b) Novel, one-step synthesis of zwitterionic polymer nanoparticles via distillation-precipitation polymerization and its application for dye removal membrane. Sci Rep 7:1-16

18. Ibrahim GS, Isloor AM, Ismail A, Farnood R (2020a) One-step synthesis of zwitterionic graphene oxide nanohybrid: Application to polysulfone tight ultrafiltration hollow fiber membrane. Sci Rep 10:1-13

19. Ibrahim S, Mohammadi Ghaleni M, Isloor AM, Bavarian M, Nejati S (2020b) Poly(Homopiperazine-Amide) Thin-Film Composite Membrane for Nanofiltration of Heavy Metal lons. ACS Omega 5:28749-28759

20. Isloor AM, Nayak MC, Inamuddin, Prabhu B, Ismail N, Ismail AF, Asiri AM (2019) Novel polyphenylsulfone (PPSU)/nano tin oxide (SnO2) mixed matrix ultrafiltration hollow fiber membranes: Fabrication, characterization and toxic dyes removal from aqueous solutions. Reactive and Functional Polymers 139:170-180

21. Jafar Mazumder MA, Raja PH, Isloor AM, Usman M, Chowdhury SH, Ali SA, Inamuddin, Al-Ahmed A (2020) Assessment of sulfonated homo and co-polyimides incorporated polysulfone ultrafiltration blend membranes for effective removal of heavy metals and proteins. Sci Rep 10:7049

22. Jayalakshmi A, Rajesh S, Mohan D (2012) Fouling propensity and separation efficiency of epoxidated polyethersulfone incorporated cellulose acetate ultrafiltration membrane in the retention of proteins. Appl Surf Sci 258:9770-9781

23. Jeevanandam J, Kulabhusan PK, Danquah MK (2019) Biofunctional Nanoparticles for Protein Separation, Purification and Detection, Horizons in Bioprocess Engineering. Springer, pp 113-156

24. Jyoti A, Singh RK, Kumar N, Aman AK, Kar M (2021) 'Synthesis and properties of amorphous nanosilica from rice husk and its composites. Mater Sci Engineering: B 263:114871

25. Krishnamoorthy L, Arif PM, Ahmedkhan R (2011) Separation of proteins from aqueous solution using cellulose acetate/poly (vinyl chloride) blend ultrafiltration membrane. J Mater Sci 46:2914-2921

26. Kumar M, Ulbricht M (2013) Novel antifouling positively charged hybrid ultrafiltration membranes for protein separation based on blends of carboxylated carbon nanotubes and aminated poly(arylene ether sulfone). J 
Membr Sci 448:62-73

27. Kumar M, McGlade D, Ulbricht M, Lawler J (2015) Quaternized polysulfone and graphene oxide nanosheet derived low fouling novel positively charged hybrid ultrafiltration membranes for protein separation. RSC Adv 5:51208-51219

28. Kumar M, RaoT S, Isloor AM, Ibrahim GPS, Inamuddin, Ismail N, Ismail AF, Asiri AM (2019) Use of cellulose acetate/polyphenylsulfone derivatives to fabricate ultrafiltration hollow fiber membranes for the removal of arsenic from drinking water. Int J Biol Macromol 129:715-727

29. Kumar M, Isloor AM, Todeti SR, Nagaraja HS, Ismail AF, Susanti R (2021) Effect of binary zinc-magnesium oxides on polyphenylsulfone/cellulose acetate derivatives hollow fiber membranes for the decontamination of arsenic from drinking water. Chem Eng J 405:126809

30. Kureha T, Nishizawa Y, Suzuki D (2017) Controlled Separation and Release of Organoiodine Compounds Using Poly(2-methoxyethyl acrylate)-Analogue Microspheres. ACS Omega 2:7686-7694

31. Lawrence Arockiasamy D, Alam J, Alhoshan M (2013) Carbon nanotubes-blended poly(phenylene sulfone) membranes for ultrafiltration applications. Appl Water Sci 3:93-103

32. Li S-F, Yang X-L, Huang W-Q (2005) PREPARATION OF MONODISPERSE CROSSLINKED POLYMER MICROSPHERES HAVING CHLOROMETHYL GROUP BY DISTILLATION-PRECIPITATION POLYMERIZATION. Chin J Polym Sci 23:197-202

33. Li T, Jiang Z, Xu C, Liu B, Liu G, Wang P, Li X, Chen W, Ning C, Wang Z (2017) Effect of pore structure on shale oil accumulation in the lower third member of the Shahejie formation, Zhanhua Sag, eastern China: Evidence from gas adsorption and nuclear magnetic resonance. Mar Pet Geol 88:932-949

34. Liu G, Yang X, Wang Y (2007) Preparation of monodisperse hydrophilic polymer microspheres with N, N'methylenediacrylamide as crosslinker by distillation precipitation polymerization. Polym Int 56:905-913

35. Liu J, Yang K, Shao W, Li S, Wu Q, Zhang S, Qu Y, Zhang L, Zhang Y (2016) Synthesis of zwitterionic polymer particles via combined distillation precipitation polymerization and click chemistry for highly efficient enrichment of glycopeptide. ACS Appl Mater Interfaces 8:22018-22024

36. Liu J, Zhang Y, Li X, Dai L, Li H, Xue B, He X, Cao W, Lu X (2020) Experimental Study on Injection and Plugging Effect of Core-Shell Polymer Microspheres: Take Bohai Oil Reservoir as an Example. ACS Omega $5: 32112-32122$

37. Liu S-H, Liu M, Xu Z-L, Wei Y-M (2018a) A polyethersulfone-bisphenol sulfuric acid hollow fiber ultrafiltration membrane fabricated by a reverse thermally induced phase separation process. RSC Adv 8:7800-7809

38. Liu W, Zhu X, Yang X, Li K, Yang Z (2018b) Preparation of highly cross-linked hydrophilic porous microspheres poly(N,N'-methylenebisacrylamide) and poly (N,N'-methylenebisacrylamide-co-acrylic acid) with an application on the removal of cadmium. Polym Adv Technol 29:2724-2734

39. Liu Y, Zhang L, Zhao N, Han Y, Zhao F, Peng Z, Li Y (2017) Preparation of molecularly imprinted polymeric microspheres based on distillation-precipitation polymerization for an ultrasensitive electrochemical sensor. Analyst 142:1091-1098

40. Lv X, Li S (2020) Graphene Oxide-Crospolyvinylpyrrolidone Hybrid Microspheres for the Efficient Adsorption of 2,4,6-Trichlorophenol. ACS Omega 5:18862-18871

41. Ma G, Su Z-G (2013) Microspheres and microcapsules in biotechnology: design, preparation and applications. CRC Press 
42. Ma W, Xu S, Li J, Guo J, Lin Y, Wang C (2011) Hydrophilic dual-responsive magnetite/PMAA core/shell microspheres with high magnetic susceptibility and ph sensitivity via distillation-precipitation polymerization. J Polym Sci Part A: Polym Chem 49:2725-2733

43. Moideen IK, Isloor AM, Qaiser AA, Ismail AF, Abdullah MS (2018) Separation of heavy metal and protein from wastewater by sulfonated polyphenylsulfone ultrafiltration membrane process prepared by glycine betaine enriched coagulation bath. Korean J Chem Eng 35:1281-1289

44. Moideen KI, Isloor AM, Ismail AF, Obaid A, Fun H-K (2016) Fabrication and characterization of new PSF/PPSU UF blend membrane for heavy metal rejection. Desalination Water Treat 57:19810-19819

45. Muqeet M, Gadhi TA, Mahar RB, Bonelli B (2020) Advanced nanomaterials for ultrafiltration membranes application, Nanomaterials for the Detection and Removal of Wastewater Pollutants. Elsevier, pp 145-160

46. Muthukumaran S, Yang K, Seuren A, Kentish S, Ashokkumar M, Stevens GW, Grieser F (2004) The use of ultrasonic cleaning for ultrafiltration membranes in the dairy industry. Sep Purif Technol 39:99-107

47. Nayak MC, Isloor AM, Moslehyani A, Ismail AF (2017) Preparation and characterization of PPSU membranes with $\mathrm{BiOCl}$ nanowafers loaded on activated charcoal for oil in water separation. J Taiwan Inst Chem Eng 77:293-301

48. Nayak MC, Isloor AM, Moslehyani A, Ismail N, Ismail A (2018) Fabrication of novel PPSU/ZSM-5 ultrafiltration hollow fiber membranes for separation of proteins and hazardous reactive dyes. J Taiwan Inst Chem Eng 82:342-350

49. Phan HT, Bartelt-Hunt S, Rodenhausen KB, Schubert M, Bartz JC (2015) : Investigation of bovine serum albumin (BSA) attachment onto self-assembled monolayers (SAMs) using combinatorial quartz crystal microbalance with dissipation (QCM-D) and spectroscopic ellipsometry (SE).PloS one10, e0141282

50. Rajesh S, Jayalakshmi A, Senthilkumar S, Sankar HSH, Mohan DR (2011) Performance Evaluation of Poly(amide-imide) Incorporated Cellulose Acetate Ultrafiltration Membranes in the Separation of Proteins and Its Fouling Propensity by AFM Imaging. Ind Eng Chem Res 50:14016-14029

51. Riedl K, Girard B, Lencki RW (1998) Influence of membrane structure on fouling layer morphology during apple juice clarification. J Membr Sci 139:155-166

52. Saralidze K, Koole LH, Knetsch MLW (2010) Polymeric Microspheres for Medical Applications. Materials 3:3537-3564

53. Sepelyak RJ, Feldkamp JR, Moody TE, White JL, Hem SL (1984) Adsorption of pepsin by aluminum hydroxide I: adsorption mechanism. J Pharm Sci 73:1514-1517

54. Shenvi SS, Isloor AM, Ahmad AL, Garudachari B, Ismail AF (2016) Influence of palm oil fuel ash, an agroindustry waste on the ultrafiltration performance of cellulose acetate butyrate membrane. Desalination Water Treat 57:26414-26426

55. van Reis R, Zydney A (2001) Membrane separations in biotechnology. Curr Opin Biotechnol 12:208-211

56. Vedadghavami A, Minoei F, Hosseini SS (2018) Practical Techniques for Improving the Performance of Polymeric Membranes and Processes for Protein Separation and Purification. Iran J Chem Chem Eng (IJCCE) 37:1-23

57. Wang B, Shao Q, Fang Y, Wang J, Xi X, Chu Q, Dong G, Wei Y (2017) Fabrication of imidazoliumfunctionalized magnetic composite microspheres for selective recognition and separation of heme proteins. New J Chem 41:5651-5659 
58. Wang J, Cormack PA, Sherrington DC, Khoshdel E (2003) Monodisperse, molecularly imprinted polymer microspheres prepared by precipitation polymerization for affinity separation applications. Angew Chem 115:5494-5496

59. Yang S, Chen G, Lv C, Li C, Yin N, Yang F, Xue L (2018) Evolution of nanopore structure in lacustrine organicrich shales during thermal maturation from hydrous pyrolysis, Minhe Basin, Northwest China. Energy Explor Exploit 36:265-281

60. Zhang J, Xu Z, Mai W, Min C, Zhou B, Shan M, Li Y, Yang C, Wang Z, Qian X (2013) Improved hydrophilicity, permeability, antifouling and mechanical performance of PVDF composite ultrafiltration membranes tailored by oxidized low-dimensional carbon nanomaterials. J Mater Chem A 1:3101-3111

\section{Tables}

Table 1 Composition of different dope solutions

\begin{tabular}{lllll} 
Membranes & PPSU & NMP & PVP & P(MBAm-co-MAA) \\
& $(\mathbf{g})$ & $(\mathrm{g})$ & $\mathbf{( g )}$ & $\mathbf{( g )}$ \\
\hline M-0 & 20.0 & 79.0 & 1 & 0 \\
\hline M-1 & 20.0 & 78.9 & 1 & 0.1 \\
\hline M-2 & 20.0 & 78.8 & 1 & 0.2 \\
\hline M-3 & 20.0 & 78.7 & 1 & 0.3
\end{tabular}

Table 2 Contact angle, water uptake and porosity of the membrane

\begin{tabular}{llll} 
Membranes & $\begin{array}{l}\text { Contact angle } \\
\left(\mathbf{(}^{\circ}\right.\end{array}$ & $\begin{array}{l}\text { Water uptake } \\
(\%)\end{array}$ & $\begin{array}{l}\text { Porosity } \\
(\%)\end{array}$ \\
\hline M-0 & 87.3 & 43.0 & 34.7 \\
\hline M-1 & 73.0 & 63.6 & 60.3 \\
\hline M-2 & 69.9 & 67.1 & 72.6 \\
\hline M-3 & 75.9 & 67.0 & 65.0
\end{tabular}

Table 3 Detailed parameters of AFM surface roughness of the membrane $M-0, M-1, M-2, M-3$ 
Membrane Image surface area $\left(\mu \mathrm{m}^{2}\right)$
Surface area difference

(\%)

Roughness

Image Ra Image Rq Image Rmax (nm) $(\mathrm{nm}) \quad(\mathrm{nm})$

\begin{tabular}{llllll}
\hline M-0 & 24.4 & 2.0 & 7.2 & 9.9 & 126 \\
\hline M-1 & 99.5 & 0.7 & 12.7 & 18.4 & 241 \\
\hline M-2 & 96.1 & 4.0 & 23.7 & 31.9 & 421 \\
\hline M-3 & 101 & 0.6 & 14.2 & 20.4 & 234
\end{tabular}

Table 4 Detailed experimental studies of the membrane antifouling nature at 2 bar pressure

\begin{tabular}{|c|c|c|c|c|c|c|c|}
\hline Membranes & $\begin{array}{l}\text { Water } \\
\text { permeability } \\
\left(\mathrm{L} \mathrm{m}^{-2} \mathrm{~h}^{-1} \mathrm{bar}^{-1}\right) \\
\left(\mathrm{Q}_{\mathrm{w} 1}\right)\end{array}$ & $\begin{array}{l}\text { BSA } \\
\text { permeability } \\
\left(L^{-2} h^{-1} \text { bar }^{-1}\right) \\
\left(Q_{w 1}\right)\end{array}$ & $\begin{array}{l}\text { Water } \\
\text { permeability } \\
\left(\mathrm{L} \mathrm{m}^{-2} \mathrm{~h}^{-1} \mathrm{bar}^{-1}\right) \\
\left(\mathrm{Q}_{\mathrm{w} 1}\right)\end{array}$ & $\begin{array}{r}\text { FRR } \\
(\%)\end{array}$ & $\begin{array}{l}\mathrm{R}_{\mathrm{t}} \\
(\%)\end{array}$ & $\begin{array}{l}\mathrm{R}_{\mathrm{r}} \\
(\%)\end{array}$ & $\begin{array}{l}\mathrm{R}_{\mathrm{ir}} \\
(\%)\end{array}$ \\
\hline$M-0$ & 35.7 & 14.0 & 18.0 & 50.4 & 60.7 & 11.2 & 49.5 \\
\hline$M-1$ & 43.9 & 25.2 & 32.3 & 73.5 & 42.6 & 16.1 & 26.4 \\
\hline M-2 & 60.0 & 37.4 & 51.2 & 85.2 & 37.7 & 22.9 & 14.7 \\
\hline M-3 & 49.7 & 29.9 & 40.2 & 80.7 & 39.9 & 20.6 & 19.2 \\
\hline
\end{tabular}

Table 5 Protein rejection and permeation studies of the membrane at 2 bar pressure

\begin{tabular}{|c|c|c|c|c|c|c|}
\hline Membranes & $\begin{array}{l}\text { BSA rejection } \\
\text { (\%) }\end{array}$ & $\begin{array}{l}\text { BSA permeability } \\
\left(\mathrm{L} \mathrm{m}^{-2} \mathrm{~h}^{-1} \mathrm{bar}^{-1}\right)\end{array}$ & $\begin{array}{l}\text { Pepsin } \\
\text { rejection } \\
\text { (\%) }\end{array}$ & $\begin{array}{l}\text { Pepsin } \\
\text { permeability (L } \\
\left.\mathrm{m}^{-2} \mathrm{~h}^{-1} \mathrm{bar}^{-1}\right)\end{array}$ & $\begin{array}{l}\text { Egg } \\
\text { albumin } \\
\text { rejection } \\
(\%)\end{array}$ & $\begin{array}{l}\text { Egg albumin } \\
\text { permeability (L } \\
\left.\mathrm{m}^{-2} \mathrm{~h}^{-1} \mathrm{bar}^{-1}\right)\end{array}$ \\
\hline$M-0$ & 68.6 & 21.4 & 36.2 & 41.0 & 40.1 & 33.1 \\
\hline M-1 & 87.4 & 33.2 & 47.8 & 45.2 & 49.8 & 36.9 \\
\hline M-2 & 94.8 & 59.2 & 68.4 & 87.3 & 86.9 & 71.0 \\
\hline M-3 & 85.2 & 37.6 & 48.2 & 65.6 & 79.1 & 61.7 \\
\hline
\end{tabular}

\section{Figures}



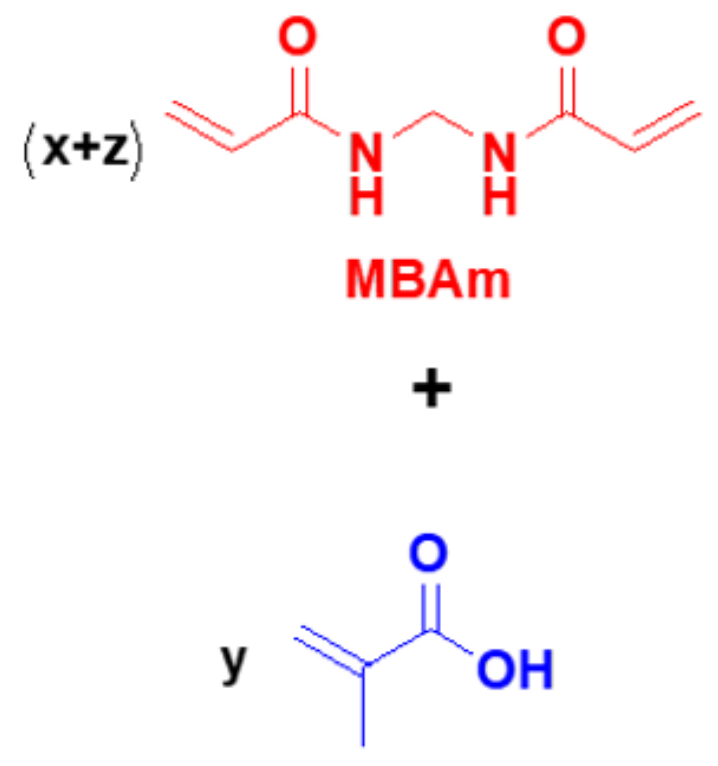

MAA

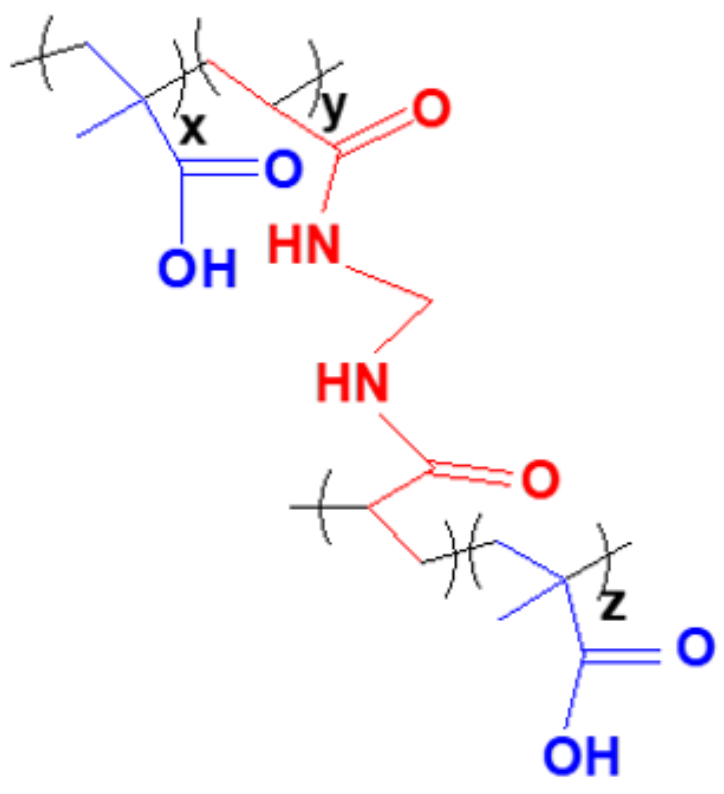

P(MBAm-co-MAA)

Figure 1

Synthetic route of the $\mathrm{P}(\mathrm{MBAm}-\mathrm{co}-\mathrm{MAA})$ microsphere 


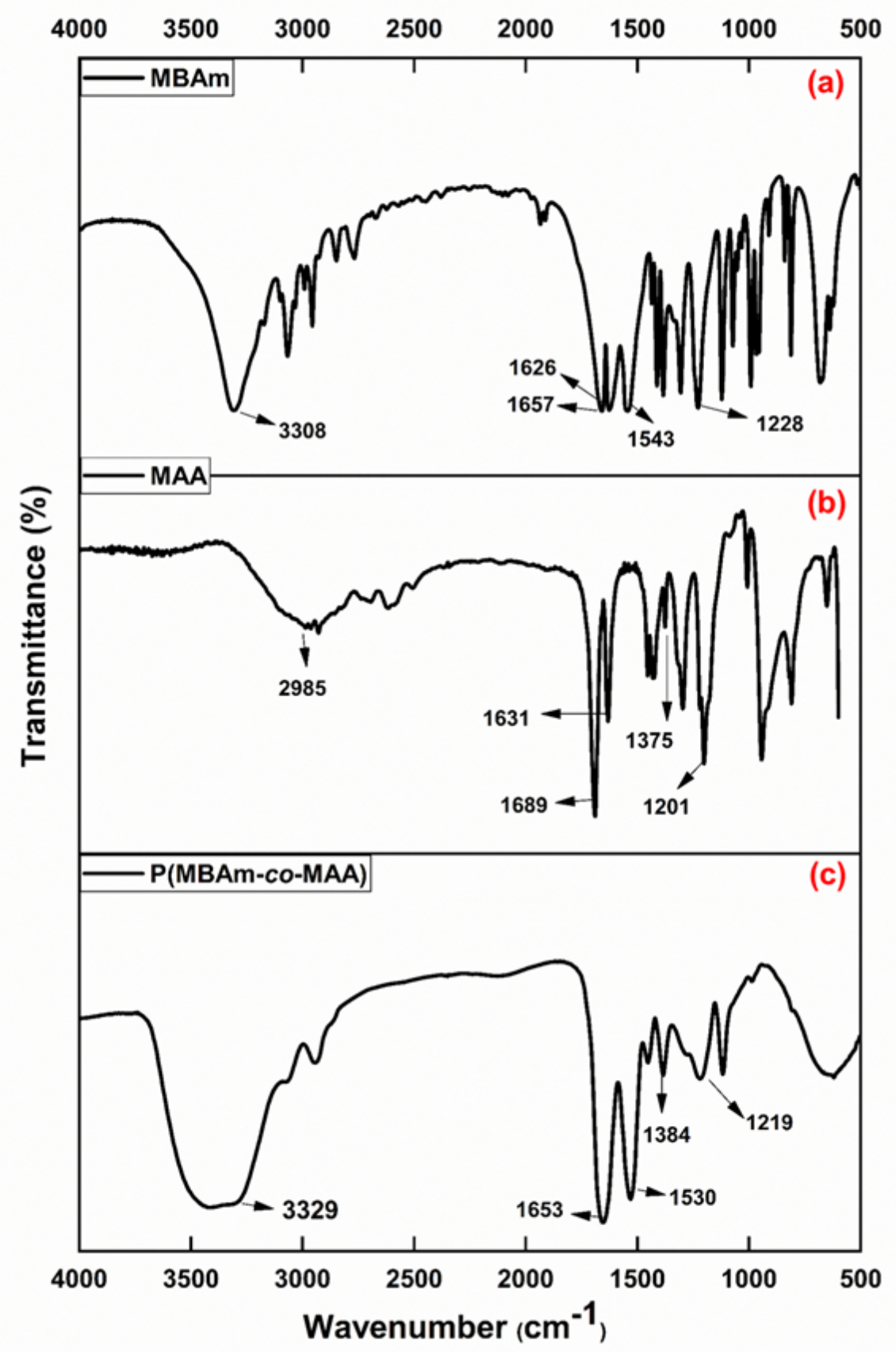

Figure 2

The ATR-FTIR spectra of (a) MBAm, (b) MAA and (c) P(MBAm-co-MAA) polymer particle. ATR-FTIR spectra were recorded using a pinch of as it is samples were directly analyzed using an instrument in the range of 4000-500 $\mathrm{cm}^{-1}$ 

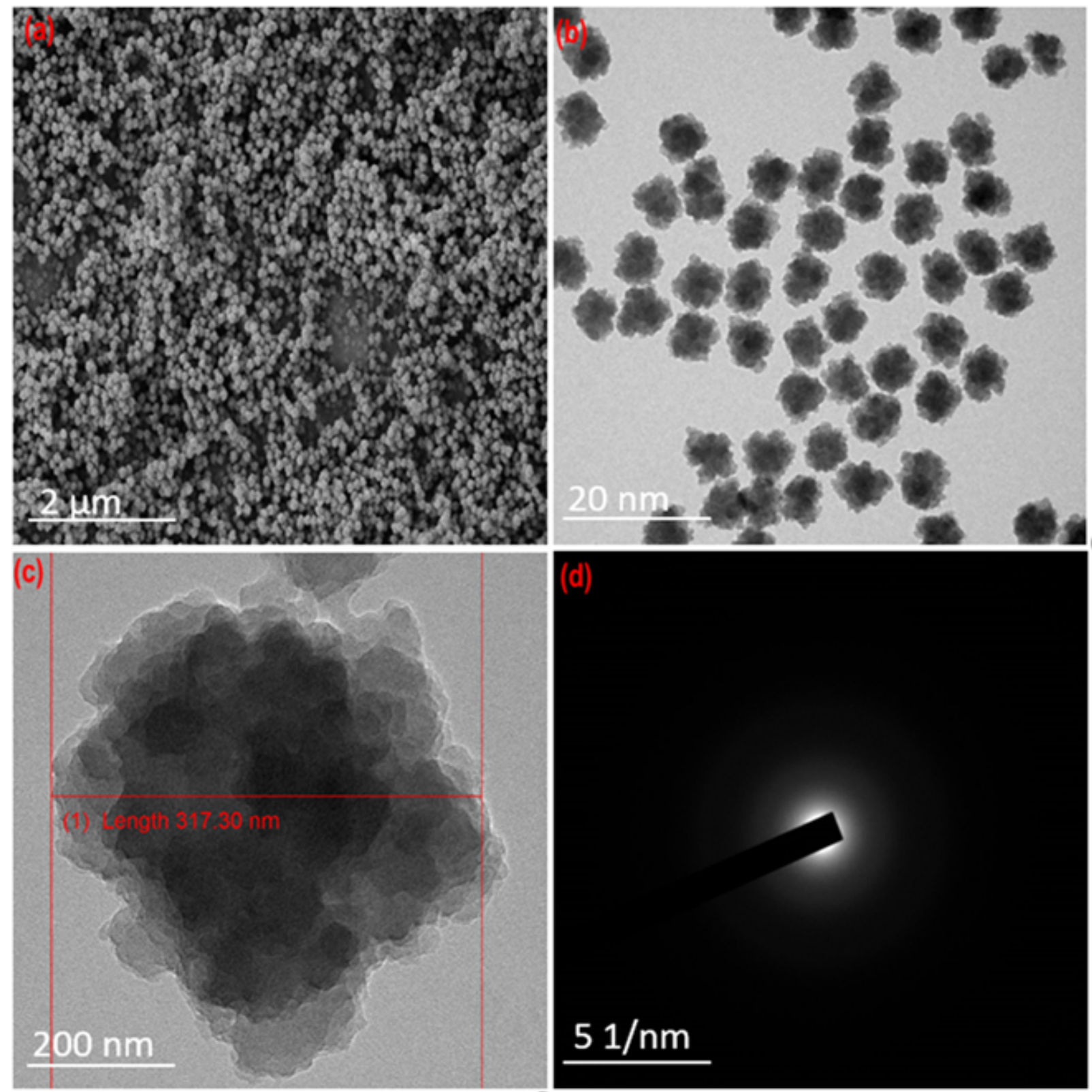

\section{Figure 3}

(a) FESEM images of $\mathrm{P}(\mathrm{MBAm}-\mathrm{Co}-\mathrm{MAA})$ with the resolution of $2 \mu \mathrm{m}$ and magnification of $10.00 \mathrm{KX}$ at $1.00 \mathrm{kV}$, (b) TEM image of $P(M B A m-C O-M A A)$ with the resolution of $20 \mathrm{~nm}$ and magnification of $8000 \mathrm{x}$ at $200 \mathrm{kV}$ without staining the samples, (c) TEM image of the single-particle size of P(MBAm-co-MAA) with the resolution of 200 $\mathrm{nm}$ and magnification of $80000 \mathrm{x}$ at $200 \mathrm{kV}$ without staining the samples, (d) SAED pattern of P(MBAm-co-MAA) with of resolution of $51 / \mathrm{nm}$ at $200 \mathrm{kV}$ and camera length $300 \mathrm{~mm}$ 

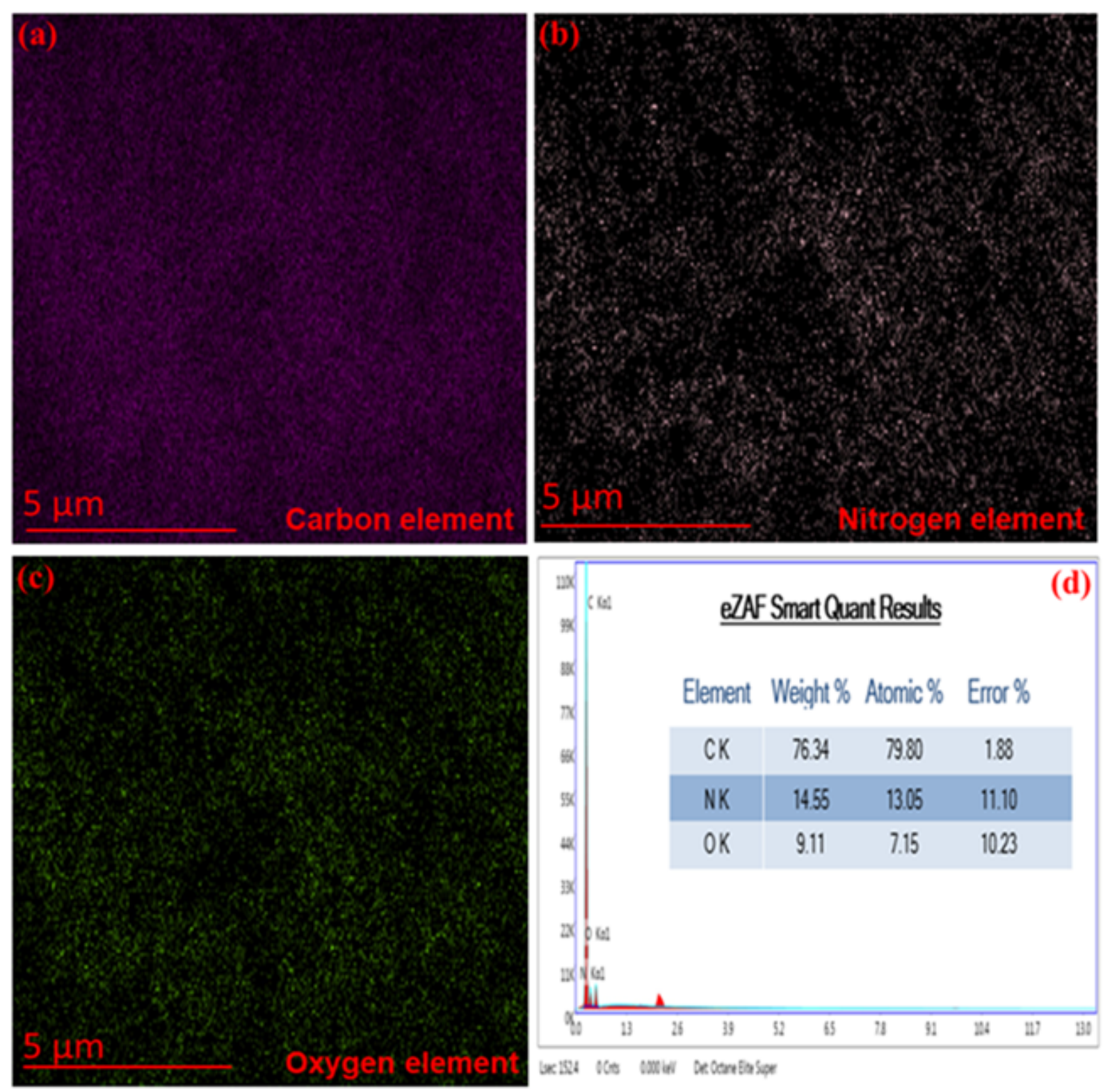

Figure 4

$(a, b, c)$ Elemental mapping of $\mathrm{P}(\mathrm{MBAm}-\mathrm{co}-\mathrm{MAA})$ of Carbon, Nitrogen and Oxygen respectively with the resolution of $5 \mu \mathrm{m}$ respectively, (d) EDX of $\mathrm{P}(\mathrm{MBAm}-\mathrm{co}-\mathrm{MAA})$ polymer particle 
(a)
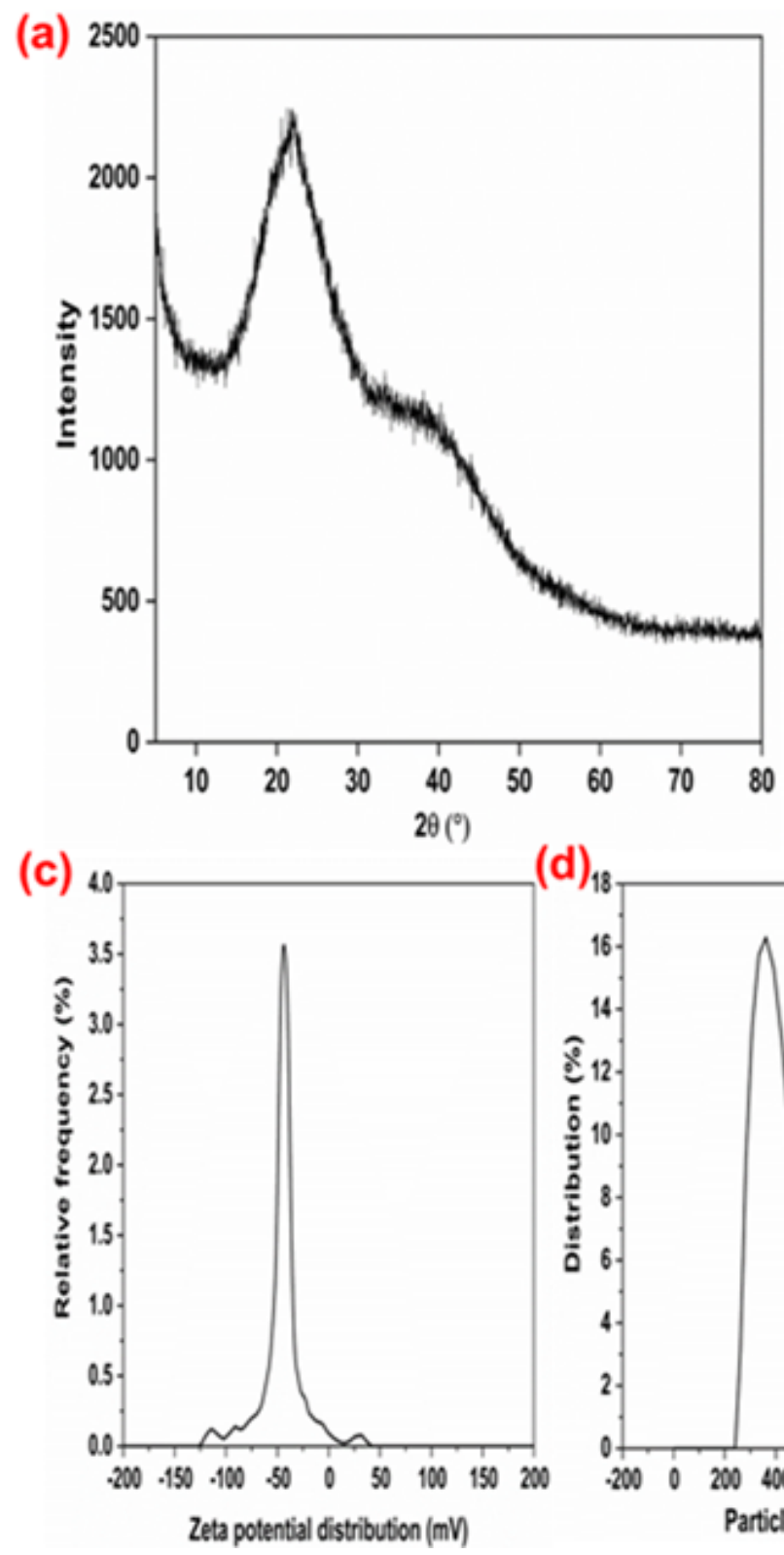

(b) 70

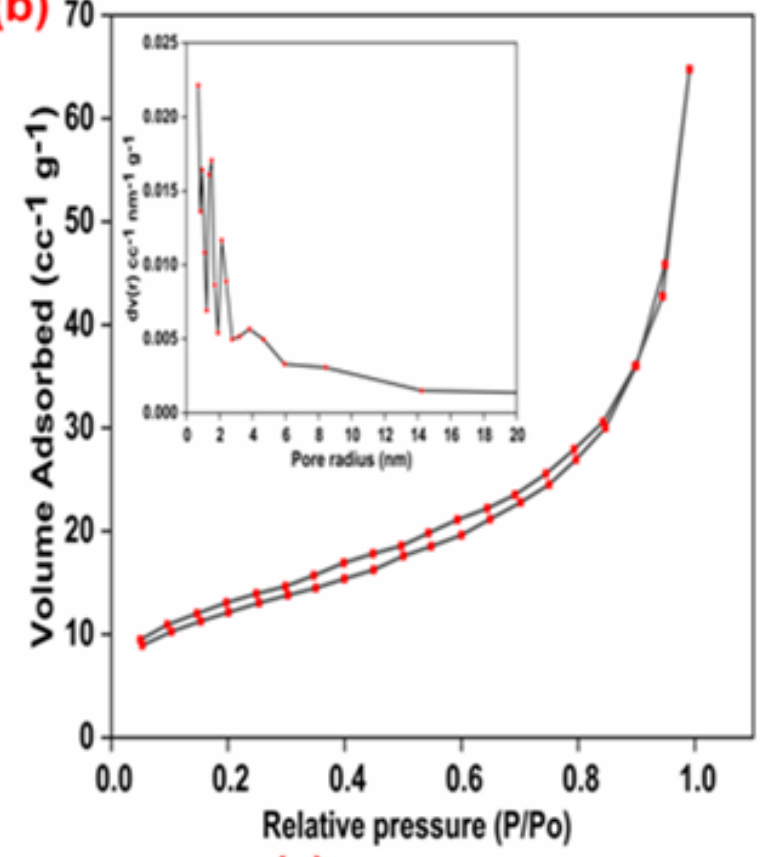

(e)
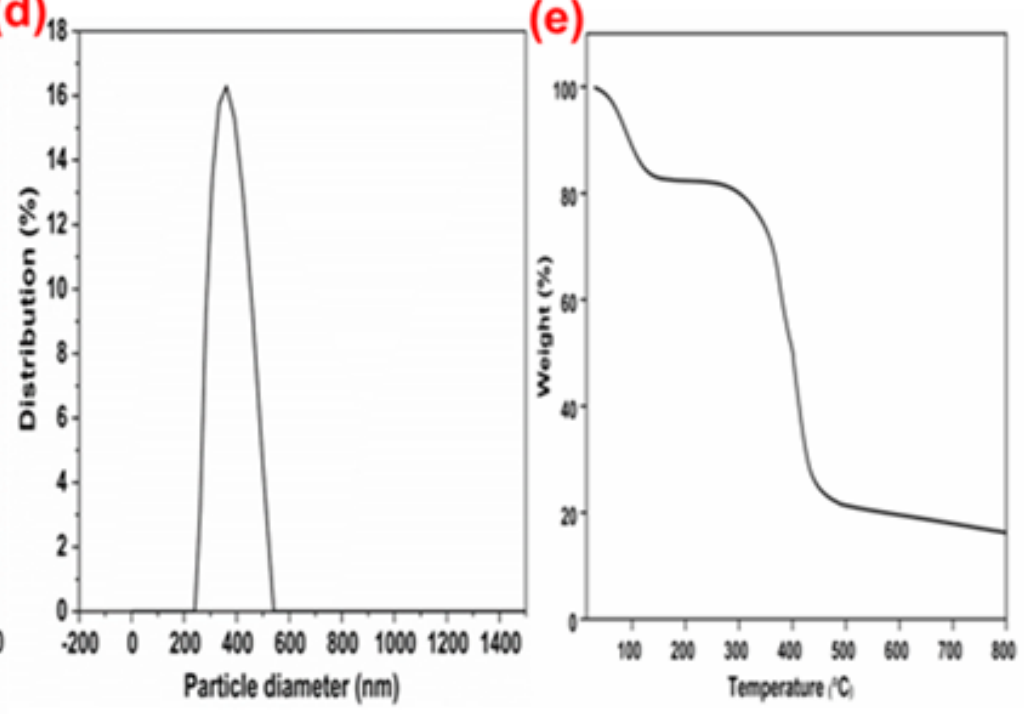

Figure 5

(a) XRD of $\mathrm{P}(\mathrm{MBAm}-\mathrm{Co}-\mathrm{MAA})$ was recorded in the range of $5-80^{\circ}$, (b) BET isotherm plot for nitrogen adsorption and the inset represents the BET surface area and distribution of pore size, (c) Zeta potential of P(MBAM-coMAA) polymer particle, (d) Hydrodynamic diameter of P(MBAm-co-MAA) microsphere (e) TGA of P(MBAm-coMAA) polymer particle 


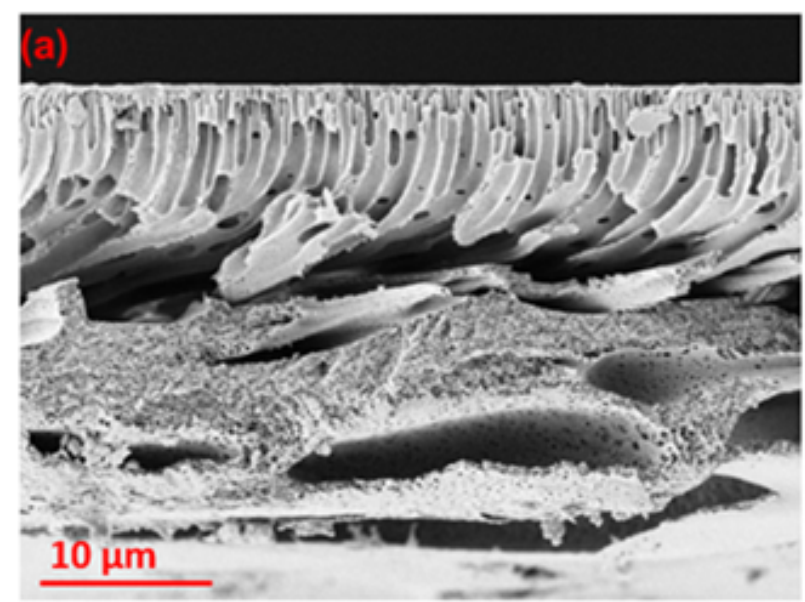

(b)

(c)
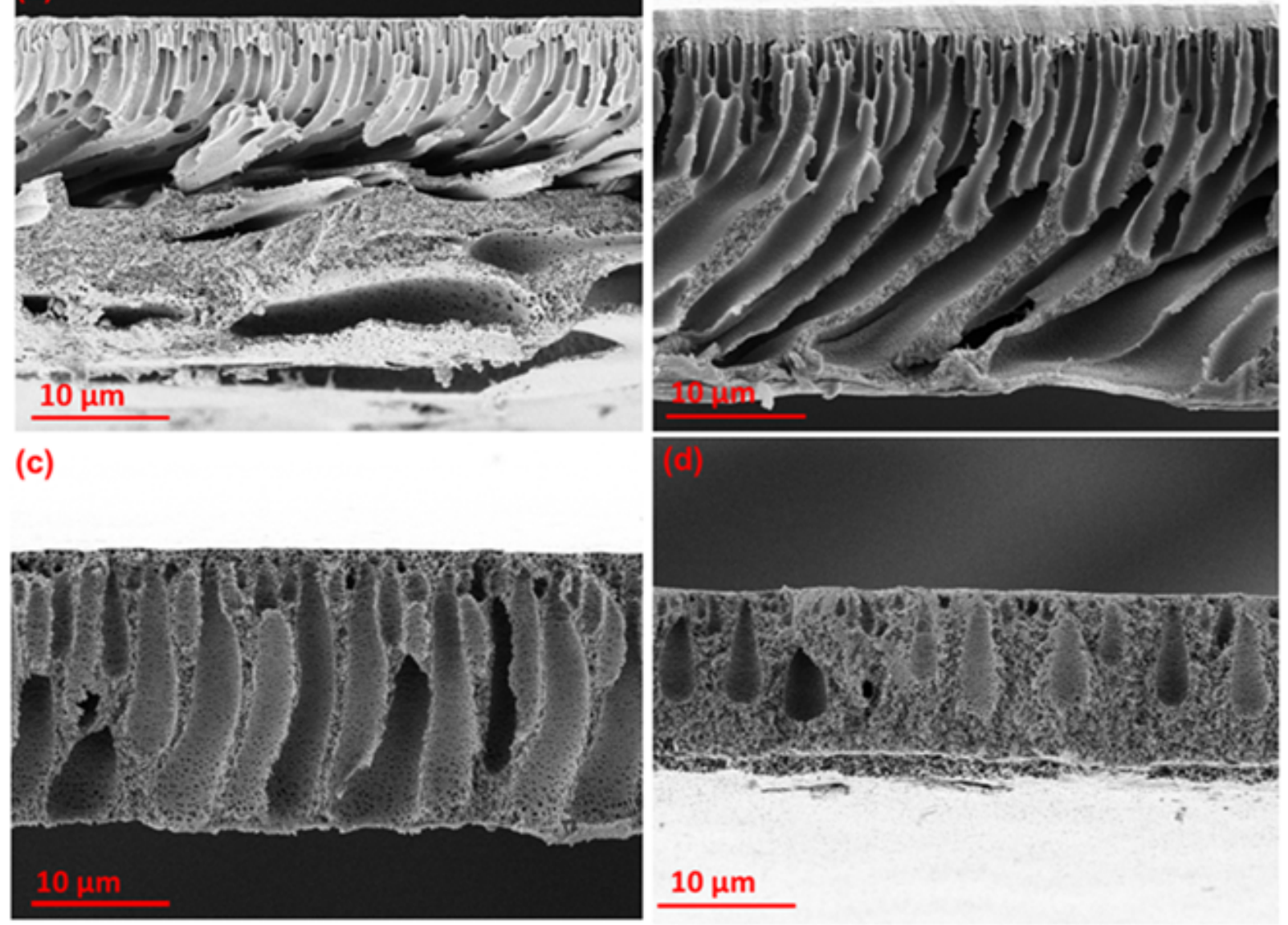

\section{Figure 6}

The cross-sectional FESEM images of the membrane: (a) M-0, (b) M-1, (c) M-2, (d) M-3 


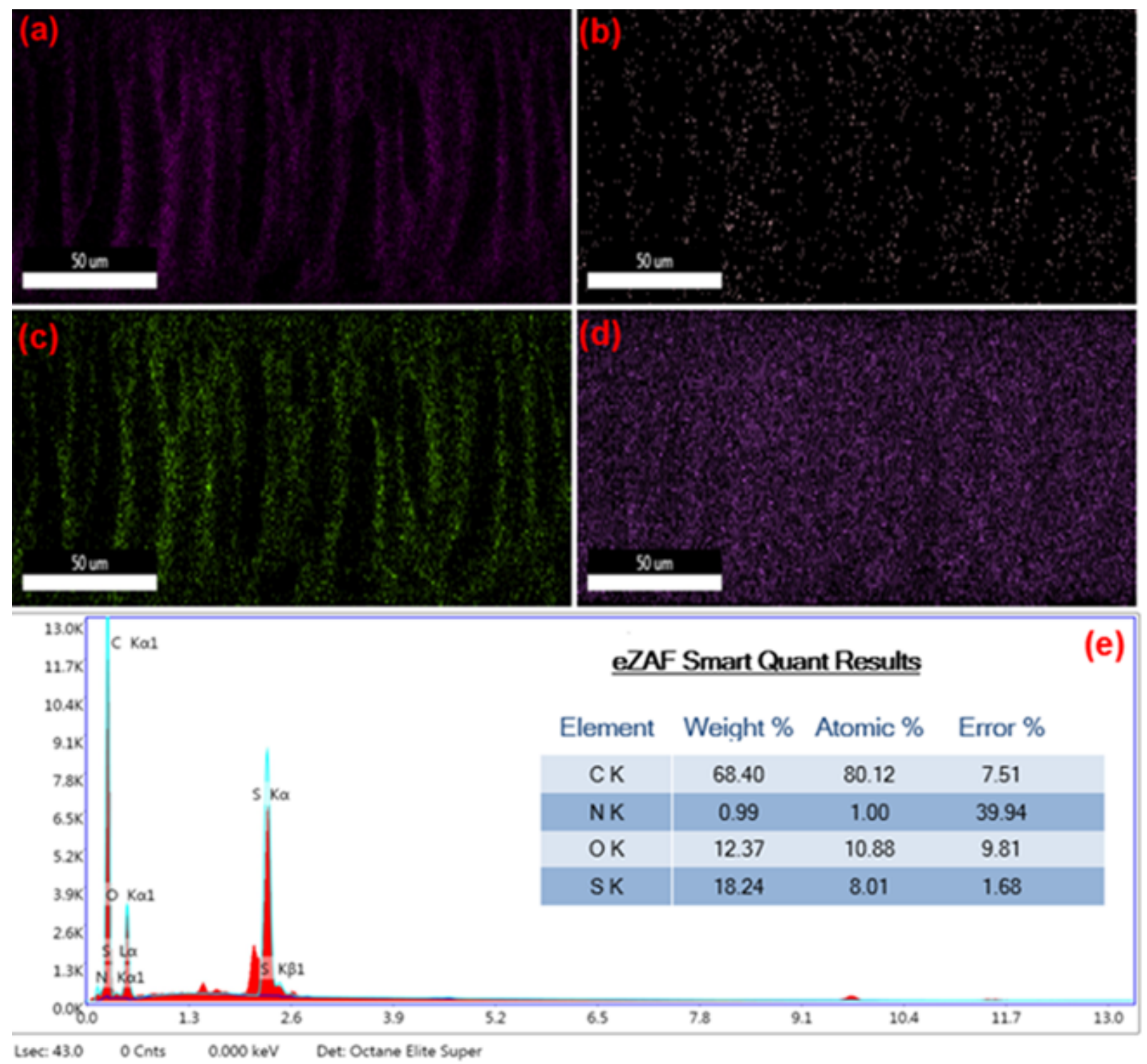

\section{Figure 7}

Elemental mapping of the membrane M-2: $(\mathbf{a}, \mathbf{b}, \mathbf{c}, \mathbf{d})$ carbon, nitrogen, oxygen and sulfur, respectively (e) EDX of the membrane M-2 

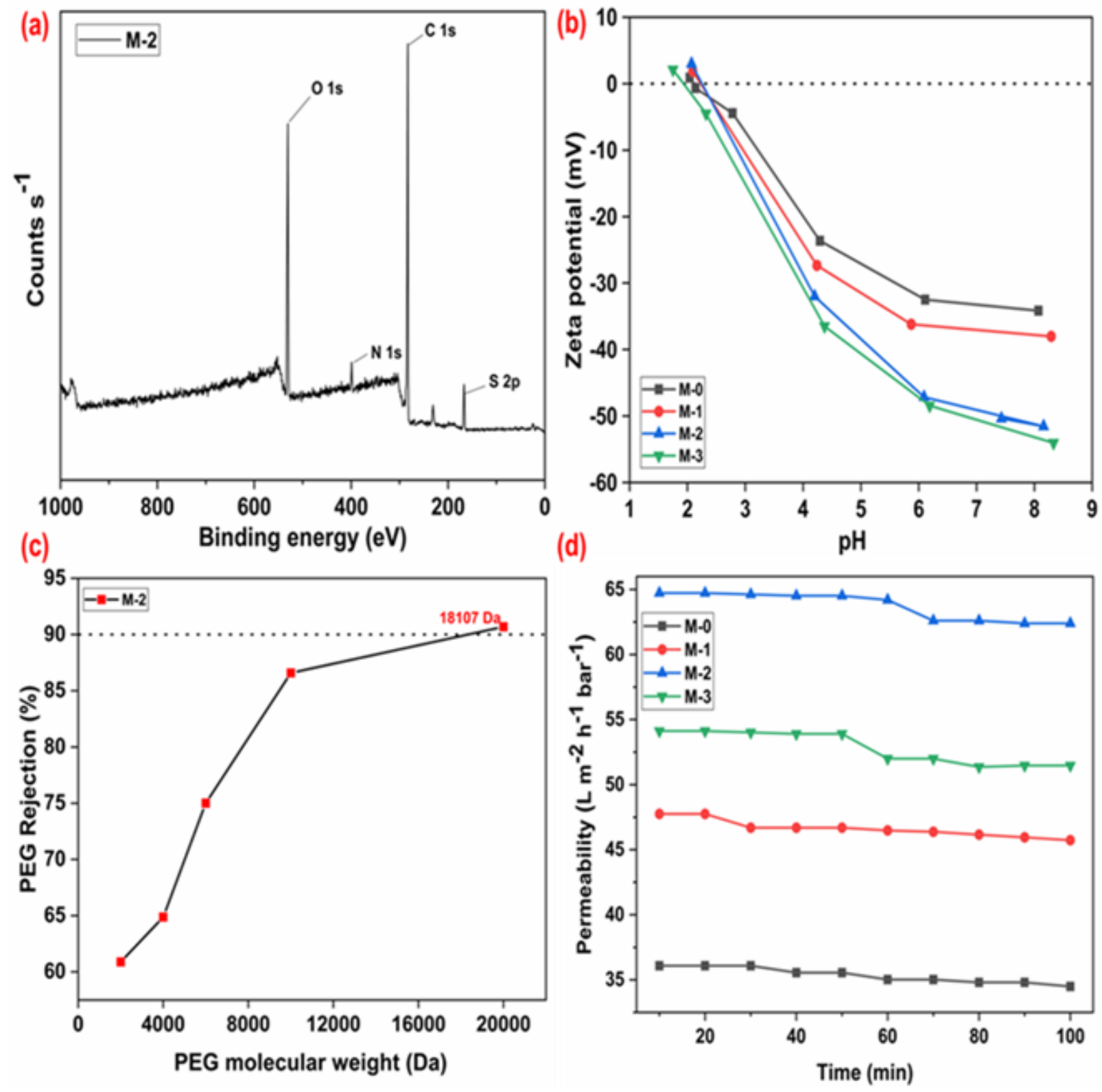

Figure 8

(a) XPS of the M-2 membrane sample (b) Zeta potential of the membrane samples M-0, M-1, M-2 and M-3 (c) Molecular weight cutoff of the membrane $M-2$ (d) Pure water permeability of the membrane M-0, M-1, M-2 and M3 samples at 2 bar pressure 


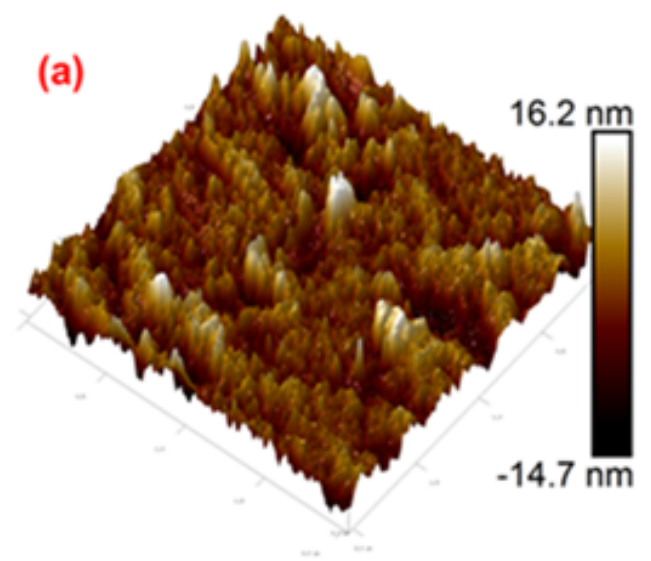

Height

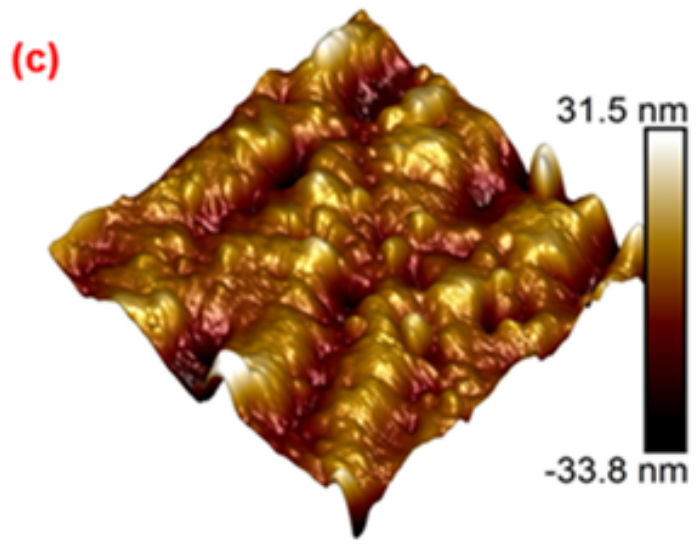

Height

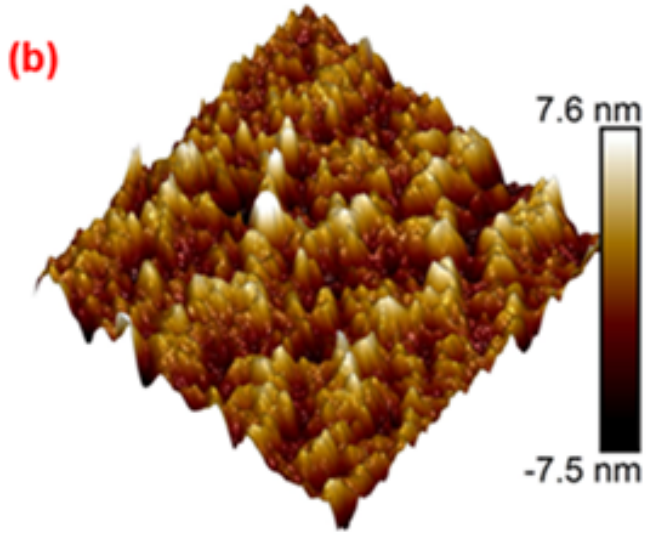

Height

(d)

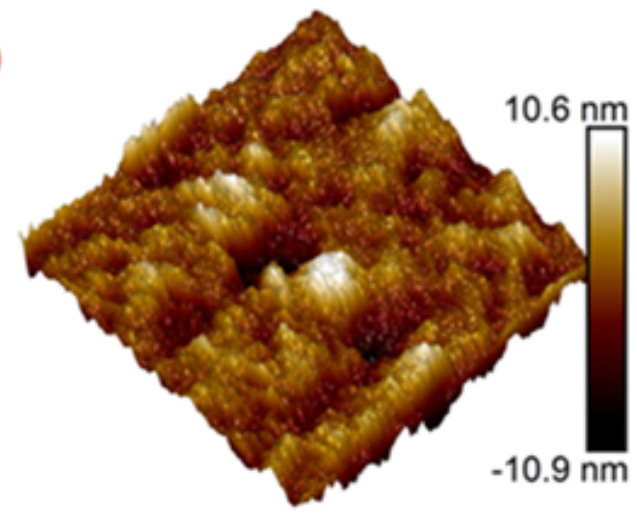

Height

Figure 9

AFM images of the membrane samples: (a) M-0, (b) M-1, (c) M-2, (d) M-3 
(a)

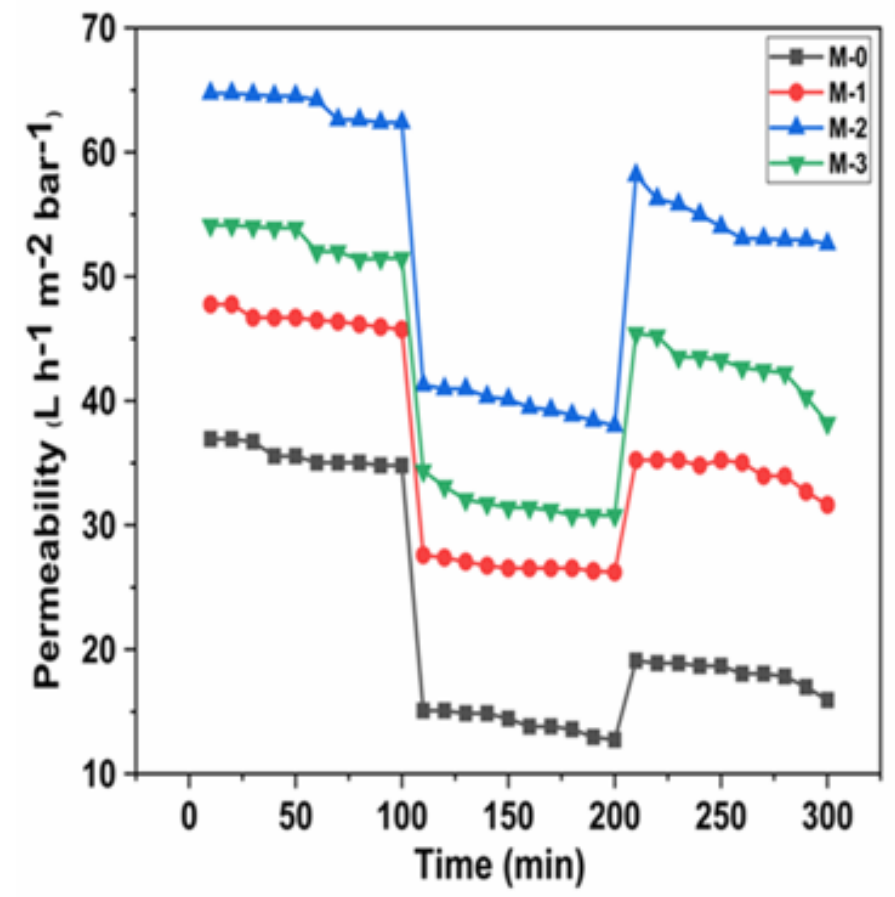

(b)

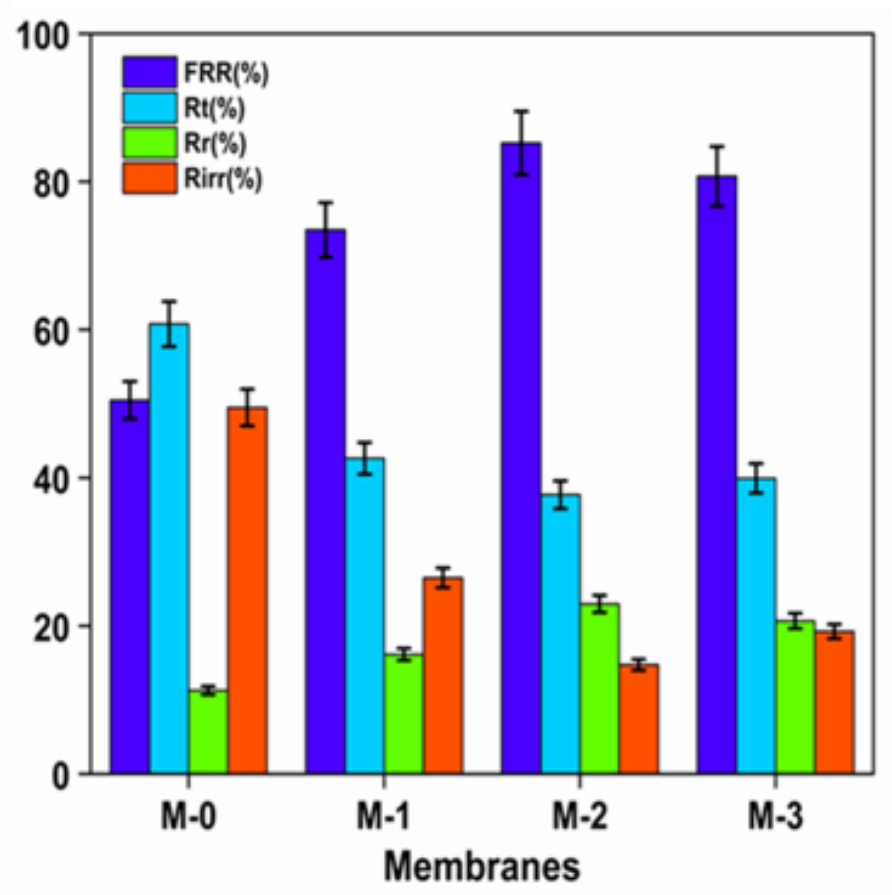

Figure 10

(a) Antifouling studies of the membrane samples, (b) Flux recovery ratio (FRR), total fouling $\left(R_{t}\right)$, Reversible fouling $\left(R_{r}\right)$, Irreversible fouling $\left(R_{\text {irr }}\right)$ at 2 bar pressure 

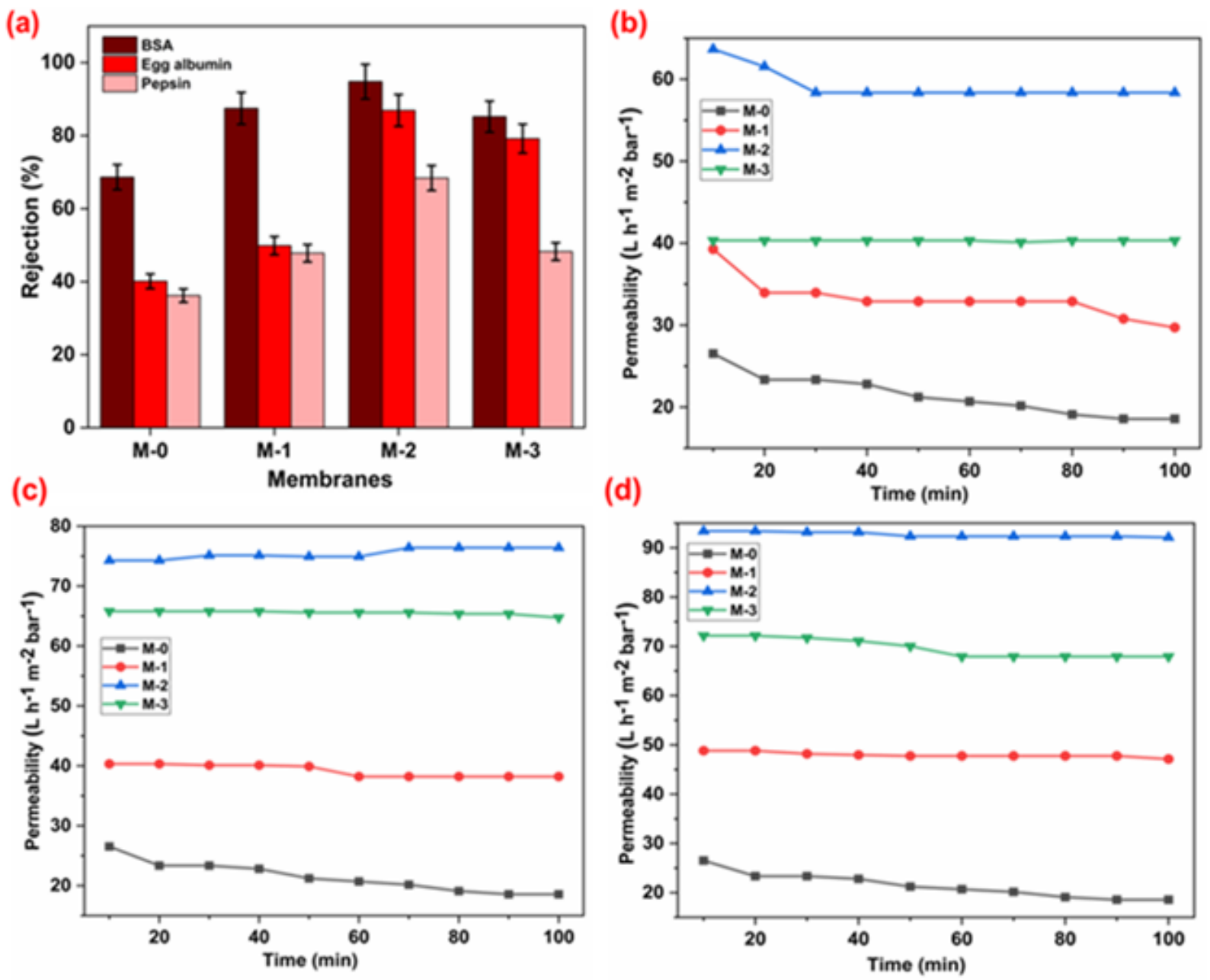

Figure 11

(a) BSA, egg albumin and pepsin proteins rejection studies of the membrane samples (b, c, d) BSA, egg albumin and pepsin permeability study, respectively at 2 bar pressure

\section{Supplementary Files}

This is a list of supplementary files associated with this preprint. Click to download.

- Graabstract.docx 